Boise State University

ScholarWorks

8-2015

\title{
High-Precision U-Pb CA-TIMS Calibration of Middle Permian to Lower Triassic Sequences, Mass Extinction and Extreme Climate- Change in Eastern Australian Gondwana
}

\author{
I. Metcalfe \\ University of New England \\ J. Crowley \\ Boise State University \\ R. S. Nicoll \\ Geoscience Australia \\ M. Schmitz \\ Boise State University
}

\section{(i) $(9)$}

This is an author-produced, peer-reviewed version of this article. (c) 2009, Elsevier. Licensed under the Creative Commons Attribution-NonCommercial-NoDerivatives 4.0 International License (https://creativecommons.org/ licenses/by-nc-nd/4.0/). The final, definitive version of this document can be found online at Gondwana Research, doi: 10.1016/j.gr.2014.09.002 
High-precision U-Pb CA-TIMS calibration of Middle Permian to Lower Triassic sequences, mass extinction and extreme climate-change in eastern Australian Gondwana

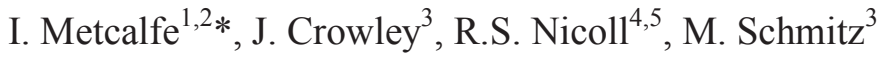

${ }^{1}$ Earth Sciences, Earth Studies Building C02, School of Environmental and Rural Science, University of New England, Armidale NSW 2351, Australia

${ }^{2}$ National Key Centre for Geochemical Evolution and Metallogeny of Continents (GEMOC), Department of Earth and Planetary Sciences, Macquarie University, NSW 2109, Australia

${ }^{3}$ Isotope Geology Laboratory, Boise State University, 1910 University Drive, Boise, ID 83725-1535, USA

${ }^{4}$ Geoscience Australia, GPO Box 378, Canberra ACT 2601, Australia

${ }^{5}$ Research School of Earth Sciences, The Australian National University, 142 Mills Road, 0200 Acton, ACT, Australia

* Corresponding author. Email: imetcal2@une.edu.au

Keywords: U-Pb zircon dating, Permian-Triassic tuffs, stage boundary placement, mass extinction, climate-change, Australian Gondwana

\section{ABSTRACT}

Twenty-eight new high-precision Chemical Abrasion Isotope Dilution Thermal Ionisation Mass Spectrometry U-Pb zircon dates for tuffs in the Sydney and Bowen Basins are reported. Based on these new dates, the Guadalupian-Lopingian/Capitanian-Wuchiapingian boundary 
is tentatively placed at the level of the Thirroul Sandstone in the lower part of the Illawarra Coal Measures in the Sydney Basin. The Wuchiapingian-Changhsingian boundary is at or close to the Kembla Sandstone horizon in the Illawarra Coal Measures, southern Sydney Basin, in the middle part of the Newcastle Coal Measures in the northern Sydney Basin, and in the middle of the Black Alley Shale in the southern Bowen Basin. The end-Permian mass extinction is recognised at the base of the Coal Cliff Sandstone in the southern Sydney Basin, at the top of the Newcastle Coal Measures in the northern Sydney Basin, and close to the base of the Rewan Group in the Bowen Basin and is dated at c. 252.2 Ma. The end-Permian mass extinction is interpreted to be synchronous globally in both marine and terrestrial environments, and in high and low latitudes (resolution $<0.5 \mathrm{my}$ ). The GSSP-defined Permian-Triassic boundary is interpreted to be approximately at the level of the Scarborough Sandstone in the lower Narrabeen Group, Sydney Basin, and in the lower Rewan Group, Bowen Basin. New dates presented here suggest that the P3 and P4 glacial episodes in the Permian of eastern Australia are early Roadian to early Capitanian, and late Capitanian to mid Wuchiapingian in age respectively. The greenhouse crisis in the uppermost Pebbly Beach and Rowan Formations of the Sydney Basin is interpreted as early mid Roadian, a mid-Capitanian age for the crisis at the base of the Illawarra/Whittingham Coal Measures is confirmed. Greenhouse crises in the upper Illawarra/Newcastle Coal Measures and lower Narrabeen Group of the Sydney Basin are dated as upper Changhsingian-Induan, and in the upper Narrabeen Group/lower Hawksbury Sandstone as upper Olenekian.

\section{Introduction}


This is an author-produced, peer-reviewed version of this article. The final, definitive version of this document can be found online at Gondwana Research, published by Elsevier Copyright restrictions may apply. doi: 10.1016/j.gr.2014.09.002

The Middle Permian to Early Triassic interval includes some of the most severe biotic crises and climate-change events in the history of the Earth. The end of the Middle Permian (end-Guadalupian) saw a profound sea-level fall, cooling event, and extinctions of low-latitude marine biota (Isozaki et al., 2007a, 2007b; Wignall et al., 2009a, 2009b). Causative mechanisms are largely linked to the Emeishan Large Igneous Province volcanism (Shellnut et al., 2012), however the global nature of the end-Guadalupian mass extinction has been questioned (Rubidge et al., 2013; Shen et al., 2013). The greatest mass extinction of life on Earth occurred in the late Changhsingian (latest Permian) with the loss of $\sim 85-90 \%$ of marine species (Jin et al., 2000; Shen et al., 2011) and $\sim 60 \%$ of terrestrial families (Benton, 1995) over a short period of time, estimated at several hundred thousands of years or less (Mundil et al., 2004; Huang et al., 2011; Shen et al., 2011; Burgess et al, 2014). Proposed killing mechanisms in the oceans include global anoxia associated with euxinia, hypercapnia (CO2 poisoning), ocean acidification, and extreme global warming. Kill mechanisms on land include increased $\mathrm{CO} 2$ and reduction of oxygen levels in the atmosphere (Schneebeli-Hermann et al., 2013), and injection of volcanic sulphate aerosols, and methane from clathrate reservoirs (Berner, 2002) with consequent global warming (Joachimski et al., 2012), aridity, wildfires, acid rain and mass wasting (Shen et al., 2013; Benton and Newall, 2014). Varied models have been proposed for the cause of the end-Permian extinction, and while hotly debated, the most widely accepted model identifies the consequences of the Siberian flood basalts as the principal cause. Following the end-Permian (late Changhsingian) mass extinction, there was a 5 million year period of continued global climatic and environmental upheaval which was characterized by significant carbon isotope excursions, the global "coal gap", "reef gap", "radiolarian gap", significant size reduction of many organisms, and a range of unusual facies and biota including microbialites, and flat pebble 
conglomerates. This Early Triassic period of environmental upheaval is referred to in the literature as the period of "delayed recovery" following the mass extinction.

Ongoing debates relating to the global nature and cause of the end-

Guadalupian mass extinction, and on the synchronous or diachronous nature and cause(s) of the end-Permian extinction require more comprehensive data both stratigraphically and geographically, and especially from regions outside of the highly studied northern hemisphere and palaeo-equatorial shallow-marine Tethyan region, i.e. from high-latitude southern hemisphere Gondwana. A major impediment to comparative studies between Permian-Triassic low and high latitude sequences and between marine and non-marine sequences has been a lack of precise geochronological constraints to effect global correlation. The P-T of the southern hemisphere Gondwana supercontinent contains predominantly endemic biotas in both marine and terrestrial environments largely precluding precise correlation with standard international biozones and System/Stage boundaries. P-T marine correlations in Australian Gondwana have previously been effected largely using local endemic brachiopod and palynology zonation schemes (Briggs 1998; Foster and Archbold, 2001). Conodonts, ammonoids and fusulinids, used globally for marine P-T biozonation are either absent (fusulinids) or rare (conodonts, ammonoids) in Gondwana and particularly in Australia due to cool-cold climatic conditions related to high southern palaeolatitudes and glaciation-influenced climatic conditions (Korte et al., 2008; Fielding et al., 2008a). Highprecision dating of multiple volcanic tuffs in these sequences now provides a robust highresolution temporal framework that can be globally correlated and can thus provide vital constraints on the nature of biotic crises, climate change and other geological events. We here present twenty-eight new high-precision $\mathrm{U}-\mathrm{Pb}$ zircon $\mathrm{CA}$-TIMS dates for $\mathrm{P}-\mathrm{T}$ air-fall tuffs in the Sydney and Bowen Basins of eastern Australian Gondwana that provide vital 
This is an author-produced, peer-reviewed version of this article. The final, definitive version of this document can be found online at Gondwana Research, published by Elsevier Copyright restrictions may apply. doi: 10.1016/j.gr.2014.09.002

international calibration and temporal framework for stratigraphy, biotic events, deep-time climate-change, tectonic evolution and resources.

\section{Geological, tectonic and palaeogeographical setting}

The Sydney, Gunnedah and Bowen basins of eastern Australia contain late Carboniferous, Permian and Triassic marine and non-marine sequences that contain substantial coal resources, particularly in the Upper Permian. These basins developed initially by back-arc extension in the late Carboniferous-Early Permian, followed by thermal sag and evolution into foreland basins in the Late Permian-Early Triassic (Korsch et al., 2009; Waschbusch et al, 2009). In the Permian-Early Triassic Australia formed part of eastern Gondwana, the southern hemisphere component of the Supercontinent Pangea and was located in high southern palaeolatitudes. An Andean-type volcano-magmatic arc produced large quantities of volcanic ash which was deposited as multiple tuffs in the Permian-Early Triassic foreland basins of eastern Australia (Fig. 1).

FIGURE 1 ABOUT HERE

Early Permian sedimentary fill of the Sydney, Gunnedah and Bowen basins, during back-arc rifting and thermal sag stages, was largely shallow-marine but in the Late Permian foreland basin stage sediments were largely non-marine terrestrial fluvial and swamp dominated with substantial coal measures development. Sequences in the SydneyGunnedah-Bowen basins have to date been largely correlated at the intra and inter-basin levels using shallow-marine biota (mainly brachiopods and forams) and palynology, and lithological and sequence stratigraphy underpinned by geophysics and borehole data. The 
This is an author-produced, peer-reviewed version of this article. The final, definitive version of this document can be found online at Gondwana Research, published by Elsevier Copyright restrictions may apply. doi: 10.1016/j.gr.2014.09.002

brachiopod, foram and palynological zonal schemes utilise largely endemic biota and these cannot be used to any degree of confidence for international correlation. In addition, the palynological zones employed are mostly long-ranging and do not provide high-resolution correlation. Rapid sedimentary facies changes, including splitting and coalescing of coal seams, together with unconformities, driven by both eustatic and tectonic regressions and transgressions in a convergent margin setting, are features of all basins. Depositional rates for sediments in the basins are poorly constrained, but are vital for understanding basin evolution and tectonic development (Korsch and Totterdel, 2009).

\section{Previous U-Pb zircon dating of tuffs in the Permian-Triassic of Eastern Australia}

There is only one previously published paper that provides U-Pb zircon TIMS ages for tuffs in eastern Australia. Gulson et al. (1990) reported an age of $256 \pm 4 \mathrm{Ma}$ for the Awaba Tuff, sampled in the BHP DDH N1561 corehole, $266 \pm 0.4$ Ma for the Thornton Claystone sampled in the roof of the Big Ben Seam near the base of the Four Mile Creek Subgroup, and $309 \pm 3$ Ma for the Matthews Gap Dacitic Tuff Member of the Patterson Volcanics, northern Sydney Basin. Zircons analysed by Gulson et al. (1990) were subject to air abrasion prior to analyses. These results lack the high-precision and accuracy of current CA-TIMS methodologies but they provided the first direct estimates for the duration of the Permian in eastern Australia and estimates of sedimentation rates for Sydney Basin sequences.

All other previously published U-Pb zircon dates for Permian-Triassic tuffs in Eastern Australia are Sensitive High Resolution Ion Microprobe (SHRIMP) dates.

Recognition of the lack of precise international correlation and calibration of CarboniferousPermian-Triassic sequences in eastern Australia led John Roberts and co-researchers to 
This is an author-produced, peer-reviewed version of this article. The final, definitive version of this document can be found online at Gondwana Research, published by Elsevier Copyright restrictions may apply. doi: 10.1016/j.gr.2014.09.002

undertake an innovative program of tuff dating to address this problem (Roberts et al., 1995a, 1995b, 1996). The results from these studies were controversial as they contradicted previously assigned ages based on biostratigraphy and in some cases indicated that rocks regarded as Permian were in fact Triassic (Draper et al., 1997). Unfortunately the Roberts et al. studies used the SL13 standard now known to have heterogeneous ${ }^{206} \mathrm{~Pb} /{ }^{238} \mathrm{U}$. Further problems with unrecognised lead loss and matrix effects on the measured $\mathrm{Pb} / \mathrm{U}$ render these SHRIMP ages unreliable (Black \& Jagodzinsky, 2003; Black et al., 2003, 2004). SHRIMP U$\mathrm{Pb}$ dating cannot achieve the fine level of time resolution required for precise timescale calibration and correlation in the Phanerozoic. Discrepancies between SHRIMP dates (Roberts et al., 1996) and early TIMS U-Pb dating in the Sydney Basin (Gulson et al., 1990) already highlighted the limitations of ion microprobe dating for time scale calibration. In this study we re-dated eight tuffs that were originally SHRIMP dated using the SL13 standard and reported by Retallack et al. (2011). CA-TIMS dates presented here are based on dating of zircons plucked from the original SHRIMP mounts for the samples reported in Retallack et al. (2011) providing a direct comparison of data (Figure 2). Comparison of these highprecision CA-TIMS dates with the SL13 based SHRIMP dates confirms the unreliability of historic SHRIMP dating in eastern Australia.

\section{FIGURE 2 ABOUT HERE}

In order to assess current SHRIMP dating of Phanerozoic tuffs using more reliable standards and as an initial screening prior to CA-TIMS dating, some of the Permian Tuff samples analysed in this study were dated by SHRIMP at Geoscience Australia. Whilst uncertainties on SHRIMP dates are still high with $2 \sigma$ uncertainties of $0.4-0.8 \%$ compared to $0.05-0.1 \%$ for CA-TIMS, the accuracy of this method is now much improved (Bodorkos et 
This is an author-produced, peer-reviewed version of this article. The final, definitive version of this document can be found online at Gondwana Research, published by Elsevier Copyright restrictions may apply. doi: 10.1016/j.gr.2014.09.002

al., 2012). Much larger individual ${ }^{206} \mathrm{~Pb} /{ }^{238} \mathrm{U}$ uncertainties in the SHRIMP datasets do not allow for recognition of marginally older xenocrysts, antecrysts or detrital grains from the interpreted magmatic grain population. In addition, lead loss issues are difficult to address by the SHRIMP method although there has been an attempt at annealing and chemical abrasion prior to SHRIMP analyses (Kryza et al., 2012). Annealing and chemical abrasion of zircon grains prior to TIMS analyses does appear to largely (but not always completely) address lead loss. The advantages of the CA-TIMS method, compared to SHRIMP makes this the preferred dating method for high-precision dating of tuffs and timescale calibration in the Phanerozoic.

\section{Isotope Geochronology}

\subsection{Materials}

Samples of volcanic tuff layers, interbedded with both non-marine and marine sedimentary strata in the Permian and Lower Triassic of the Sydney and Bowen Basins of eastern Australia were sampled from borehole cores, underground and open-cut coal mines, road cutting sections and quarries, and natural exposures in river valleys and coastal beaches. Regional tuff marker horizons were especially targeted, but in addition, sampling of tuffs to provide as comprehensive as possible stratigraphic coverage was undertaken. Sample sizes varied depending on the source, but at outcrop exposures, sample sizes were 5-10 kilograms whereas in borehole cores samples could be less than a kilogram. Due to the largely felsic nature of the tuffs, most samples yielded sufficient numbers of zircons for analyses.

\subsection{Sample locations and horizons}


Sample locations are plotted on Fig. 3 and precise co-ordinates and stratigraphic assignments are summarized in Table 1. Additional notes and stratigraphic context of some samples are given below.

FIGURE 3 ABOUT HERE

TABLE 1 ABOUT HERE

\subsubsection{Sydney Basin}

SHRIMP dates for samples PCF16, PCF17, PCF18, PCF23, PCF24, PCW266

(Table 1) were reported (but not fully presented) by Carr et al. (2003) and Retallack et al. (2011). Those dates are considered unreliable due to the use of the inhomogeneous SL13 standard (see Section 3 and Fig. 2). CA-TIMS analyses were performed on zircons plucked from the original SHRIMP mounts provided by the Australian National University. The locations of some of these samples were erroneously reported by Retallack et al. (2011) and where necessary are corrected here following discussions with Paul Carr and Brian Jones of the University of Wollongong.

PCF16: $2 \mathrm{~m}$ below the top of the Broughton Formation from outcrop near Wollongong at GPS S34.408237 E150.87857.

PCF17: Garie Formation, road cut outcrop, Bulli Tops, Wollongong area, GPS S34.32926 E150.8762321. The precise stratigraphic location within the section exposed at Bulli Tops (Fig. 4), which contains several tuff layers, was not reported by Carr et al. (2003) or 
Retallack et al. (2011). Brian Jones (pers. comm.) has indicated to us that the sample probably came from the thick tuff from which dated sample Bulli 5 (GA2005209) was taken (Fig. 4).

PCF18: This sample is from the Fairford Formation, Jerrys Plains Subgroup, Wittingham Coal Measures, Hunter Coalfield exposed in outcrop at Mount Arthur Mine, SSW of Muswellbrook (Fig. 3), GPS S32.329063 E150.86629. The precise level of this sample within the thin c. $2 \mathrm{~m}$ thick Fairford Formation is not known.

PCF23: This sample is from the Farmborough Claystone, outcrop exposures in the Nattai River, Wollongong area (Fig. 3), GPS S34.43569 E150.45639. The detailed stratigraphic level within the Farmborough Claystone is not known.

PCF24: This sample is from a tuff within the Wongawilli Coal, $1 \mathrm{~m}$ above the Farmborough Claystone, Illawarra Coal Measures, in outcrop exposures in the Nattai River, Wollongong area (Fig. 3), GPS S34.43569 E150.45639.

PCW266: Huntley Claystone Member, Illawarra Coal Measures. From corehole Tower DDH 20, $600.37 \mathrm{~m}$ depth, $6 \mathrm{~km}$ southeast of Appin (Fig. 3), S34.185243 E150.884432 (locality details from Brian Jones UW). This sample was erroneously reported as being from the Nattai River by Retallack et al. (2011).

SB27 (GA2127413): Bulli Coal Seam, Illawarra Coal Measures, Metropolitan Colliery, Peabody Energy, GPS S34.187047 E150.992334. Sample collected from underground exposures. Representative section is in Excel Metropolitan DDH3 located $500 \mathrm{~m}$ from underground sample location. Sample is from a 1-2 cm thick lenticular tuff in the lower part of the $3.25 \mathrm{~m}$ thick Bulli Seam, $0.61 \mathrm{~m}$ above the base of the seam (Fig. 5).

Bulli 5 (GA2005209): Late Lower Triassic Garie Formation, outcrop in road cutting, western side of the Southern Freeway, Bulli Tops near Wollongong, S34.32926 E150.8762321. 
This is an author-produced, peer-reviewed version of this article. The final, definitive version of this document can be found online at Gondwana Research, published by Elsevier Copyright restrictions may apply. doi: 10.1016/j.gr.2014.09.002

Sample Bulli 5 is from the middle part of a $1.8 \mathrm{~m}$ thick felsic tuff near the base of the Garie Formation (Fig. 4).

FIGURE 4 ABOUT HERE

FIGURE 5 ABOUT HERE

GA2031204: Nobbys Tuff, Newcastle Coal Measures, Centennial Borehole PN072 (Fig. 3), 171.57 - 172.67m, GPS S33.016116, E151.52842. The Nobbys Tuff in PN072 is $1.74 \mathrm{~m}$ thick and sample GA2031204 is from the upper part of the tuff (Fig. 6)

FIGURE 6 ABOUT HERE

GA2031203: Awaba Tuff regional thick tuff marker bed in the Newcastle Coal Measures, was sampled in Centennial Coal/ Mandalong DDH 95 (Fig. 3, Fig. 7), 284.63 - 285.44m, GPS S33.1216825, E151.425355. The Awaba Tuff in the Mandalong DDH 95 core is 11.39 $\mathrm{m}$ thick, with top at $283.96 \mathrm{~m}$ and base at $295.35 \mathrm{~m}$ and sample GA2031203 is from the uppermost part. The Awaba Tuff is overlain by the West Wallarah coal seam that is the local name used at Mandalong to define the seam formed by the westerly convergence of the Wallarah and Great Northern seams. The Awaba Tuff is underlain by the Fassifern Seam (see Fig. 7).

FIGURE 7 ABOUT HERE 
Myuna 2 (GA2128524): Great Northern Seam, Newcastle Coalfield. Myuna Mine

(underground exposures), GPS S33.0631786, E151.569965. Sample horizon is $170 \mathrm{~cm}$ above the base of the Great Northern Seam (Fig. 8).

FIGURE 8 ABOUT HERE

GA2055445: Mannering Park Tuff, Moon Island Beach Fm, Newcastle Coal Measures, Centennial Coal, Myuna DDH 45 (Fig. 3, Fig. 9, Fig. 14), 0.70 - 1.70m, GPS S33.0718, E151.5988. The sampled $1 \mathrm{~m}$ thick tuff underlies the Wallarah Coal (Fig. 9).

FIGURE 9 ABOUT HERE

GA2152418: Cowper Tuff, Newcastle Coal Measures, sampled in outcrop below the Karignan Conglomerate and above the Wallarah Coal seam, at Ghosties Beach (Fig. 3, Fig. 14), GPS S33.1774139, E151.6297194.

GA2031207: Rowan Fm, Greta Coal Measures, Hunter Coalfield, Muswellbrook Coal Sandy Creek MCC, Sandy Creek DDH 32 (Fig. 3), 266.91 - 267.07 m. GPS S32.226753, E150.933751. The $16 \mathrm{~cm}$ thick tuff is located in the upper part of the Rowan Formation, approximately $11 \mathrm{~m}$ below the top of the formation and between the Fleming and Hilltop coal seams (see Boyd and Leckie, 2000 for stratigraphic horizon). This tuff was dated using the SHRIMP as $268.9 \pm 2.0 \mathrm{Ma}$ (Roberts et al., 1996).

GA2005149: Fairford Fm, Lower Jerrys Plains Subgroup, Wittingham Coal Measures, Hunter Coalfield, AMOCO Wybong 1 (Fig. 3), 595.9 - 596.21m. GPS S32.27502, E150.65368. 
GA2005146: Nobbys Tuff (lower part), Clifford Fm, Wollombi Coal Measures, Hunter Coalfield, AMOCO Wybong 1, 255.33 - 255.6m. GPS S32.27502, E150.65368. See Creech et al. (2004) for relevant stratigraphic section.

M2 (GA2129584), M3 (GA2129585), M4 (GA2129586): Samples of the Upper Pilot A Interbeds (M4), lower Fassifern Seam (M3) and Awaba Tuff (M2), Newcastle Coal Measures were collected from the Mangoola Mine (Xstrata) near Muswellbrook in the Hunter Coalfield (Fig. 10).

FIGURE 10 ABOUT HERE

GA2005145: Awaba (formerly called Nalleen) Tuff Member (lower part), Newcastle Coal Measures, Hunter Coalfield. AMACO Wybong 1, 94.92 - 95.2m. GPS S32.27502, E150.65368. See Creech et al. (2004) for relevant stratigraphic sections.

\subsubsection{Bowen Basin}

We here report CA-TIMS ages from eight samples from the Upper Permian sequence in the southern Bowen Basin.

Myall Creek 3: A $34 \mathrm{~cm}$ thick air fall tuff in the Tinowon Fm, Wallabella Coal Member, Myall Creek 3 drill core, depth 2077.01 - 2077.35 m, near the base of an 8.6 m thick reworked tuffaceous sst/mudstone unit within the Wallabella Coal Member, 1m above the top of the Main Seam (Fig.3, Fig. 11). A SHRIMP date of 257.0 \pm 1.5 Ma was reported for this tuff by McInnes et al. (2010). Unfortunately this included session calibration against the 
This is an author-produced, peer-reviewed version of this article. The final, definitive version of this document can be found online at

unreliable SL13 standard. The high-precision CA-TIMS date reported here for this tuff is $256.50 \pm 0.04 \mathrm{Ma}$ which is younger than but consistent within error of the SHRIMP date.

FIGURE 11 ABOUT HERE

Meeleebee 5 samples: Seven high-precision CA-TIMS dates are here reported for tuffs in the Meeleebee 5 exploration well core, southern Bowen Basin located at GPS S26.241774, E149.197463. The depths of dated tuff samples are given in Table 1 and their horizons in relation to stratigraphy are given in Fig. 12.

FIGURE 12 ABOUT HERE

\subsection{CA-TIMS U-Pb Geochronology Methods}

$\mathrm{U}-\mathrm{Pb}$ dates were obtained by the chemical abrasion isotope dilution thermal ionization mass spectrometry (CA-TIMS) method from analyses composed of single zircon grains or fragments of grains. Most samples were prepared at Boise State University, where grains were separated from tuffs using standard techniques, placed in a muffle furnace at $900^{\circ} \mathrm{C}$ for 60 hours in quartz beakers, mounted in epoxy, polished until the centers of the grains were exposed, and imaged for cathodoluminescence (CL). Samples were similarly prepared at the Australian National University, with the difference being that grains were U$\mathrm{Pb}$ dated by SHRIMP and annealed after being removed from mounts. Zircon was selected for analysis based on the CL images and several grains were broken into two fragments that were analyzed separately to test for within-grain age uniformity. Zircon was subjected to a modified version of the CA-TIMS method of Mattinson (2005). Single grains or fragments of 
grains were loaded into $300 \mathrm{ml}$ Teflon PFA microcapsules, 15 of which were placed in large capacity Parr vessels, and were partially dissolved in $120 \mathrm{ml}$ of $29 \mathrm{M} \mathrm{HF}$ for 12 hours at $180^{\circ} \mathrm{C}$. Residual zircon was placed into $3 \mathrm{ml}$ Teflon PFA beakers, HF was removed, and 3.5 $\mathrm{M} \mathrm{HNO}_{3}$ was added. Zircon was ultrasonically cleaned for 0.5 hour and fluxed on a hotplate at $80^{\circ} \mathrm{C}$ for several hours. The $\mathrm{HNO}_{3}$ was removed and zircon rinsed twice in ultrapure $\mathrm{H}_{2} \mathrm{O}$ before being put back into $300 \mathrm{ml}$ Teflon PFA microcapsules, which were rinsed and fluxed in $6 \mathrm{M} \mathrm{HCl}$ for several hours. EARTHTIME ${ }^{233} \mathrm{U}^{235} \mathrm{U}_{-}{ }^{202} \mathrm{~Pb}-{ }^{205} \mathrm{~Pb}$ tracer solution (ET2535) or EARTHTIME ${ }^{233} \mathrm{U}_{-}{ }^{235} \mathrm{U}_{-}{ }^{205} \mathrm{~Pb}$ tracer solution (ET535) was added to the microcapsules before the zircon was dissolved in $120 \mathrm{ml}$ of $29 \mathrm{M} \mathrm{HF}$ with a trace of $3.5 \mathrm{M} \mathrm{HNO}_{3}$ at $220^{\circ} \mathrm{C}$ for 48 hours, dried to fluorides, and then re-dissolved in $6 \mathrm{M} \mathrm{HCl}$ at $180^{\circ} \mathrm{C}$ for 10 hours. $\mathrm{U}$ and $\mathrm{Pb}$ were separated from the zircon matrix using an $\mathrm{HCl}$-based anion-exchange chromatographic procedure (Krogh, 1973), eluted together and dried with $2 \mu 1$ of $0.05 \mathrm{~N}$ $\mathrm{H}_{3} \mathrm{PO}_{4}$.

$\mathrm{Pb}$ and $\mathrm{U}$ were loaded on a single outgassed Re filament in $5 \mu \mathrm{l}$ of a silicagel/phosphoric acid mixture (Gerstenberger and Haase, 1997), and $\mathrm{U}$ and $\mathrm{Pb}$ isotopic measurements made on a GV Isoprobe-T multicollector thermal ionization mass spectrometer equipped with an ion-counting Daly detector. $\mathrm{Pb}$ isotopes were measured by peak-jumping all isotopes on the Daly detector for 160 cycles. For the analyses with the ET2535 tracer solution, $\mathrm{Pb}$ mass fractionation was determined by the measured ${ }^{202} \mathrm{~Pb} /{ }^{205} \mathrm{~Pb}$. For analyses with the ET535 tracer solution, $\mathrm{Pb}$ mass fractionation was taken to be $0.18 \pm 0.06 \%$ (2s) per atomic mass unit based on results from analyses with ET2535. Transitory isobaric interferences due to high-molecular weight organics, particularly on ${ }^{204} \mathrm{~Pb}$ and ${ }^{207} \mathrm{~Pb}$, disappeared within approximately 30 cycles, while ionization efficiency averaged $10^{4} \mathrm{cps} / \mathrm{pg}$ of each $\mathrm{Pb}$ isotope. Linearity (to $\geq 1.4 \times 10^{6} \mathrm{cps}$ ) and the associated deadtime correction of the Daly detector were monitored by repeated analyses of NBS982, and have been constant since 
installation. Uranium was analyzed as $\mathrm{UO}_{2}{ }^{+}$ions in static Faraday mode on $10^{11} \mathrm{ohm}$ resistors for 250 cycles, and corrected for isobaric interference of ${ }^{233} \mathrm{U}^{18} \mathrm{O}^{16} \mathrm{O}$ on ${ }^{235} \mathrm{U}^{16} \mathrm{O}{ }^{16} \mathrm{O}$ with an ${ }^{18} \mathrm{O} /{ }^{16} \mathrm{O}$ of 0.00206 . Ionization efficiency averaged $20 \mathrm{mV} / \mathrm{ng}$ of each $\mathrm{U}$ isotope. $\mathrm{U}$ mass fractionation was corrected using the known ${ }^{233} \mathrm{U} /{ }^{235} \mathrm{U}$ ratio of the ET535 tracer solution.

$\mathrm{U}-\mathrm{Pb}$ dates and uncertainties were calculated using the algorithms of Schmitz and Schoene (2007), ET2535 and ET535 tracer solution calibrations (Condon et al., in prep.; McLean et al., in prep.) of ${ }^{235} \mathrm{U} /{ }^{205} \mathrm{~Pb}=100.233,{ }^{233} \mathrm{U} /{ }^{235} \mathrm{U}=0.99506,{ }^{202} \mathrm{~Pb} /{ }^{205} \mathrm{~Pb}=0.99924$ (ET2535), and ${ }^{205} \mathrm{~Pb} /{ }^{204} \mathrm{~Pb}=11268$ (ET535) or ${ }^{205} \mathrm{~Pb} /{ }^{204} \mathrm{~Pb}=10900$ (ET2535), and U decay constants recommended by Jaffey et al. (1971). ${ }^{206} \mathrm{~Pb} /{ }^{238} \mathrm{U}$ ratios and dates were corrected for initial ${ }^{230} \mathrm{Th}$ disequilibrium using a Th/U[magma $]=3.0 \pm 0.6(2 \mathrm{~s})$ using the algorithms of Crowley et al. (2007), resulting in an increase in the ${ }^{206} \mathrm{~Pb} /{ }^{238} \mathrm{U}$ dates of $\sim 0.09 \mathrm{Ma}$. All common $\mathrm{Pb}$ in analyses (average is $0.54 \mathrm{pg}$ ) is attributed to laboratory blank and subtracted based on the measured laboratory $\mathrm{Pb}$ isotopic composition and associated uncertainty. $\mathrm{U}$ blanks are difficult to precisely measure, but are estimated at $0.075 \mathrm{pg}$.

Seven to 19 dates per sample were obtained (average is nine grains). Three to nine equivalent dates per sample (average is seven dates) that are interpreted as representing the deposition age of the tuffs are included in weighted mean ${ }^{206} \mathrm{~Pb} /{ }^{238} \mathrm{U}$ dates calculated using Isoplot 3.0 (Ludwig, 2003). Errors on the weighted mean dates are the internal errors based on analytical uncertainties only, including counting statistics, subtraction of tracer solution, and blank and initial common $\mathrm{Pb}$ subtraction. They are given at the $2 \mathrm{~s}$ confidence interval for weighted mean dates with probability of fit $>0.05$ and at the $95 \%$ confidence interval for dates with probability of fit $<0.05$. These errors should be considered when comparing our dates with ${ }^{206} \mathrm{~Pb} /{ }^{238} \mathrm{U}$ dates from other laboratories that used the same EARTHTIME tracer solution or a tracer solution that was cross-calibrated using EARTHTIME gravimetric standards. When 
comparing our dates with those derived from laboratories that did not use the same

EARTHTIME tracer solution or a tracer solution that was cross-calibrated using

EARTHTIME gravimetric standards, a systematic uncertainty in the tracer calibration of $0.05 \%$ should be added to the internal error in quadrature. When comparing our date with those derived from other decay schemes (e.g., ${ }^{40} \mathrm{Ar} /{ }^{39} \mathrm{Ar},{ }^{187} \mathrm{Re}-{ }^{187} \mathrm{Os}$ ), systematic uncertainties in the tracer calibration and ${ }^{238} \mathrm{U}$ decay constant (Jaffey et al., 1971) should be added to the internal error in quadrature. Results below are given with errors in the format of $\pm \mathrm{x} / \mathrm{y} / \mathrm{z}$ where $\mathrm{x}$ is the internal error, $\mathrm{y}$ is the error including tracer calibration uncertainty, and $\mathrm{z}$ is the error including decay constant uncertainty. Errors on the ${ }^{206} \mathrm{~Pb} /{ }^{238} \mathrm{U}$ dates from individual analyses are given at the 2 s confidence interval.

\subsection{U-Pb Geochronology Results}

Deposition ages of the tuffs are interpreted from the weighted mean dates given in Table 2. For full analytical results see Table 3 (on-line supporting material). Most samples have a few older dates that are interpreted as being from grains that were xenocrysts or antecrysts in the magma that produced the volcanoes or detrital grains that were incorporated into the tuff. Much rarer are younger dates that are interpreted as being from grains that suffered $\mathrm{Pb}$ loss that was not eliminated by chemical abrasion.

TABLE 2 ABOUT HERE

\section{System/Series/Stage Boundary Placements in Eastern Australia}

\subsection{Capitanian-Wuchiapingian (Guadalupian-Lopingian) boundary}


FIGURE 13 ABOUT HERE

The Capitanian-Wuchiapingian (C-W)/Guadalupian-Lopingian (G-L)

boundary is a GSSP defined Stage/Series boundary and is formally designated at the golden spike at the base of Bed 6k in the GSSP section at Penglaitan, South China, which correlates with the first appearance of the conodont sub-species Clarkina postbitteri postbitteri within an evolutionary cline (Jin et al., 2006a). The age of the G-L GSSP boundary is poorly constrained and is interpreted to be 259.8 +/- 0.4 Ma by Gradstein et al. (2012). This is an interpolated age between a top Wordian tie point age from USA and a mid-Wuchiapingian tie point age from China and there is no dated tuff bed close to this boundary (see Figure 24.10 of Gradstein et al. 2012). A new high-precision CA-TIMS date of 259.1 $\pm 0.5 \mathrm{Ma}$ for a felsic ignimbrite near the top of the Emeishan lava succession in SW China (Zhong et al., 2014) suggests that the age of the G-L boundary is close to this age. The International Commission on Stratigraphy's Permian Subcommission has now adopted this date for the G-L boundary (Angiolini, 2014). Carbonate carbon isotope data from the GSSP define a rather minor broad positive excursion, the peak of which essentially coincides with the GSSP defined boundary (Wang et al., 2004) and a very short-lived sharp peak of $\sim 1 \%$ at the top of the J. granti zone (Chen et al., 2011). A larger negative $\delta^{13} \mathrm{C}$ isotope excursion observed above the endGuadalupian mass extinction level is interpreted as a result of lower abundance of marine biomass after the extinction (Yan et al., 2013; Liu et al., 2013). In shallow water low-latitude mid-Panthalassa deposits (Kamura section, Japan) a positive excursion similar to that observed at the GSSP coincides with the G-L boundary (Isozaki et al., 2007b). Lowresolution organic C-isotope data for the lower Illawarra Coal Measures in corehole PHKB1 (Birgenheier et al., 2010 - see Fig. 13) suggests, by correlation with carbonate C-isotope data 
from the GSSP (Hyuskens et al., 2013), that the G-L boundary could be interpreted to be close to the level of the Thirroul Sandstone. Apart from the limited C-isotope data, there is little to constrain the G-L boundary level in eastern Australia due to lack of globally correlatable biostratigraphy or magnetostratigraphy. The recent $\mathrm{U}-\mathrm{Pb}$ isotopic dates from the Karoo (Rubidge et al., 2013) unfortunately do not help much because tetrapod vertebrates are extremely rare in eastern Australia (Warren, 1997). To further exacerbate matters, the limestones at the GSSP section are re-magnetized precluding detailed magnetostratigraphic correlation.

Placement of the G-L boundary, currently interpreted to be $259.1 \pm 0.5 \mathrm{Ma}$, at the level of the Thirroul Sandstone is consistent with the bracketing ages of $263.51 \pm 0.05 \mathrm{Ma}$ for the top Broughton Formation and 254.86 \pm 0.03 Ma for the Huntley Claystone (Fig. 13). This level also correlates with the P4 glacial episode, and is coincident with both eastern Australian and global major regression and low sea level stand at that time (Fig. 13). This position seems more consistent with global climatic shifts that may be linked to the Emeishan LIP which has both intrusives and extrusives limited to the time interval 260-259 Ma (Shellnut et al., 2012; Zhong et al., 2014; Fig. 13).

\subsection{Wuchiapingian-Changhsingian boundary}

The Wuchiapingian-Changhsingian boundary is defined in the GSSP section at a point in the lower part of Bed 4 (base of 4a-2) $88 \mathrm{~cm}$ above the base of the Changxing Limestone at Meishan D section, China (Jin et al., 2006b). The base Changhsingian is recognised at the GSSP by the First Appearance Datum (FAD) of the conodont Clarkina wangi Zhang. The base of the Changhsingian is dated at 254.2 Ma (Shen et al., 2011; Gradstein et al, 2012) and equates approximately with the level of the Kembla Sandstone 
horizon in the southern Sydney Basin by interpolation between dates of $254.86 \pm 0.03 \mathrm{Ma}$ (Huntley Claystone) and 254.10 $\pm 0.07 \mathrm{Ma}$ (Farmborough Claystone), see Fig. 13. In the Newcastle and Hunter coalfields area of the northern Sydney Basin, the WuchiapingianChanghsingian boundary can be placed within the middle part of the Newcastle (Wollombi) Coal Measures (Fig. 14). In the Bowen Basin, seven new high-precision U-Pb CA-TIMS ages of tuffs from core samples of the Meeleebee 5 exploration well determine the placement of the Wuchiapingian-Changhsingian boundary in the middle part of the Black Alley Shale

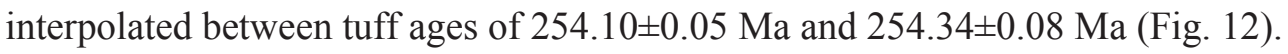

FIGURE 14 ABOUT HERE

\subsection{Permian-Triassic boundary}

Global studies of the P-T transition in complete sequences, and definition of the Permian-Triassic boundary at the GSSP section at Meishan, China (Yin et al., 2001) now place the main mass extinction horizon in the latest Permian (late Changhsingian). The P-T boundary as currently defined at the GSSP in China is placed at the base of Bed 27c coinciding with the first appearance of the conodont species Hindeodus parvus (Kozur and Pjatakova). This level is $16 \mathrm{~cm}$ above the main mass extinction level in the condensed Meishan section D (Yin et al., 2001; Jin et al., 2000; Shen et al., 2011) but up to tens of meters above the extinction level in other expanded sections. The time difference between mass extinction and GSSP level is currently estimated at between 60 and $110 \mathrm{Ka}$ (Shen et al., 2011; Burgess et al., 2014).

The P-T boundary and mass extinction levels in Eastern Australia occur in foreland basin non-marine strata and broadly coincide with a major change in 
sedimentological regime from coal-bearing peat mire strata to overlying braided river sandstone-dominated "red bed" sequences devoid of coal (Foster et al., 1998; Michaelsen, 2002). The top of the Permian has traditionally been taken at the top of the youngest coal. Biostratigraphically the P-T boundary in Eastern Australia (Fig. 15) has been interpreted to occur where the Permian Glossopteris flora (and its representative striated pollen) disappear (become extinct) and are replaced suddenly by the Dicroidium seed fern flora (Retallack, 1995). It has been estimated that the vast majority (c. 95\%) of peat-producing plants became extinct at this level which is placed at the boundary between the Rangal Coal Measures/Bandanna Formation and the Rewan Group in the Bowen Basin (Fig. 12; Michaelsen, 2002). The equivalent horizon in the Sydney Basin (Figs 13, 14 and 15) occurs at the boundary between the Illawarra/Newcastle Coal Measures and Narrabeen Group and in the Gunnedah Basin between the Black Jack Group and the Digby Sandstone Formation (Pratt, 1998). Significant changes in palaeosol types representing major changes in environments and ecosystems at the mass extinction level in the Sydney Basin (Retallack, 1999; 2013) are also recorded. Palynological studies have established a series of palynozones in the Permian-Triassic (Fig. 15) but correlation of these zones with global P-T transitional sequences has proved tenuous at best (Foster et al., 1998). Major changes in palynomorph compositions are however recognised at the extinction level including a dramatic increase in acritarchs which are interpreted to reflect major climatic changes at this level (Retallack, 1995; Foster et al., 1998). Stable carbon isotope data (Fig. 16) provides an additional proxy constraint on the end-Permian mass extinction level. The globally recognised negative $\delta^{13} \mathrm{C}$ isotope excursion has been recognised in Australia in both non-marine and marine sequences (Morante and Herbert, 1994; Morante et al., 1994; Morante, 1995, 1996; Hansen et al., 2000; Thomas et al., 2004; Grice et al., 2005; Williams et al., 2012). In Eastern Australia the $\delta^{13} \mathrm{C}$ isotope negative excursion occurs in the basal part of the Rewan Group in the Bowen Basin 
This is an author-produced, peer-reviewed version of this article. The final, definitive version of this document can be found online at Gondwana Research, published by Elsevier Copyright restrictions may apply. doi: 10.1016/j.gr.2014.09.002

and within the Protohaploxypinus microcorpus palynology zone (Morante 1995) (Fig. 16) interpreted to be of late Changhsingian age (Metcalfe et al., 2008). In the Sydney Basin, the $\delta^{13} \mathrm{C}$-isotope negative excursion occurs at the top of the Newcastle Coal Measures in the northern Sydney Basin (Morante, 1996) and in the lower Wombarra Claystone $1 \mathrm{~m}$ above the top of the Bulli Coal in the southern Sydney Basin (Williams et al., 2012; Fig. 13; Fig. 16). These excursions in the Sydney Basin correspond to the mass extinction level.

FIGURE 15 ABOUT HERE

FIGURE 16 ABOUT HERE

The P-T boundary in Western Australia occurs in shallow-marine sequences known only in the sub-surface but which have been penetrated by a number of exploratory boreholes. Palynological zones (Eyles et al, 2002) are broadly comparable to those of Eastern Australia (Fig. 16) but the occurrence of international marine biostratigraphically useful biota (such as conodonts and ammonoids) are rare (Metcalfe et al., 2008). Fusulinids are absent from Australian marine strata. Biostratigraphic, chemostratigraphic and biomarker studies of borehole cores from the Permian-Triassic transition in the Perth Basin indicate that the main mass extinction level corresponds to the Inertinitic-Sapropelic intervals boundary in the Hovea Member of the lower Kockatea Shale Formation which corresponds to the $P$. microcorpus palynology zone and that the GSSP defined P-T boundary is located in the basal part of the Sapropelic interval corresponding to the lower part of the Kraeuselisporites saeptatus palynology zone (Thomas et al., 2004; Metcalfe et al., 2008; Gorter et al., 2009). The P-T transition was penetrated in a series of boreholes in the Paradise area of the Canning Basin and the P-T boundary was interpreted to coincide with the boundary between the 
Hardman Formation and overlying Blina Shale based on the $\delta^{13} \mathrm{C}$-isotope negative excursion at this level which also occurs within the P. microcorpus palynology zone (Morante, 1996; Gorter et al., 2009). This level is here interpreted as the late Changhsingian mass extinction level. Similarly in the Bonaparte Basin, the mass extinction level is recognised by the $\delta^{13} \mathrm{C}$ isotope negative excursion occurring in the basal Mt. Goodwin Formation of borehole Fishburn 1 and in the Penguin Formation of borehole Tern 3 (Fig. 16) and within the $P$. microcorpus palynology zone (Morante, 1996; Gorter et al., 2009). There is an interpreted unconformity at the base of the P. microcorpus palynology zone in the Bonaparte Basin. The P-T boundary (GSSP level) was dated at 252.17 Ma at the GSSP by Shen et al. (2011) but more recently revised to $251.902 \pm 0.024$ by Burgess et al. (2014) using EARTHTIME $202 \mathrm{~Pb}-205 \mathrm{~Pb}-233 \mathrm{U}-235 \mathrm{U}$ tracer solution, changes in the isotopic compositions of standards used to calibrate the tracer, and new error propagation algorithms for the dating of bracketing tuffs. The P-T GSSP defined boundary is placed approximately at the level of the Scarborough Sandstone in the southern Sydney Basin (Fig. 13) based on interpolation between ages of tuffs in the Wongawilli Coal (253.59 $\pm 0.05 \mathrm{Ma})$, lower Bulli Coal $(252.60 \pm 0.04 \mathrm{Ma})$ and Garie Formation late Olenekian ages (248.23 $\pm 0.13 \mathrm{Ma} ; 247.87 \pm 0.11$ Ma). The mass extinction level, slightly older than the GSSP defined P-T boundary, is here equated with the base of the Coal Cliff Sandstone (Fig. 15), corresponding to extinction of the Glossopteris flora (Retallack, 1995) and negative carbon isotope excursion (Morante, 1996; Birgenheier et al., 2010; Williams et al., 2012). There appears to be no significant unconformity/break at the base of the Coal Cliff Sandstone (Herbert, 1997). According to Herbert (1997) the P. microcorpus palynology zone extends up to the upper part of the Wombarra Claystone indicating that the P-T boundary is above this within the lower part of the L. pellucidus zone within the Scarborough Sandstone. This placement is consistent with an interpolated P-T boundary age of c. $252 \mathrm{Ma}$ in the Southern Sydney Basin, and latest 
Permian dates in the Newcastle-Hunter region of the northern Sydney Basin here presented.

In addition, this age is also consistent with a date of $252.2 \pm 0.4 \mathrm{Ma}$ for a tuff at the top of the Bandanna Formation in the Bowen Basin (Mundil et al., 2006) which overlaps within error with the Permian-Triassic boundary age at the GSSP. The base of the Triassic in the Bowen Basin has traditionally been placed at the boundary of the coal-bearing Blackwater Group and the base of the Rewan Group ( $1 \mathrm{~m}$ above the dated level). The P-T mass extinction would be placed at the level of extinction of wetland coal forming plants (Glossopteris flora) and just above the last Permian coal in the basin near the top of the laterally equivalent Rangal Coal Measures and Bandanna Formation. Correlation with marine P-T transitional strata in the Perth basin of Western Australia is consistent with a placement of the P-T GSSP level in the lower part of the L. pellucidus zone (Metcalfe et al., 2008).

\subsection{Induan-Olenekian boundary}

The Induan-Olenekian boundary is dated at 251.3 Ma by Mundil et al. (2010) and at 251.22 $\pm 0.20 \mathrm{Ma}$ (Ovtcharova et al., 2006; Burgess et al., 2014) but at 250.00 Ma in the new Geologic Timescale 2012 (Gradstein et al., 2012). The new younger age for this boundary in Gradstein et al. (2012) is based on cyclo/magnetostratigraphy and ammonoid data. A robust age for this boundary awaits resolution of problems correlating ammonoid and conodont biostratigraphy and robust callibration of cyclo/magnetostratigraphy.

Due to the apparent lack of tuffs at this interval in Australia, the InduanOlenkian boundary is placed within the Narrabeen Group and is tentatively suggested by interpolation to be in the Bulgo Sandstone in the southern Sydney Basin (Fig. 13).

\subsection{Olenekian-Anisian (Lower-Middle Triassic) boundary}


Two dates from the Garie Formation (Fig. 13) in the southern Sydney Basin $(248.23 \pm 0.13 \mathrm{Ma} ; 247.87 \pm 0.11 \mathrm{Ma})$ are slightly older than the Olenekian-Anisian boundary dated at 247.2 Ma (Mundil et al., 2010; Gradstein et al., 2012) and indicate that the O-A boundary should be placed slightly above this level, possibly at the base of the Hawksbury Sandstone, where there is an unconformity in the Sydney Basin (Fig. 13).

\section{Discussion}

\subsection{Nature and age of the end-Guadalupian extinction.}

The global nature of the end-Guadalupian mass extinction is questionable.

Some extreme viewpoints have even suggested that there is no evidence for an end-

Guadalupian mass extinction based on diversity trends (Clapham et al., 2009). Where

continuous deposition can be demonstrated in low-latitude palaeoequatorial settings (as at the

G-L GSSP section in China) the mass extinction pre-dates the newly defined base

Wuchiapingian and occurs within the Capitanian. The Capitanian mass extinction affects a range of shallow-marine biota including algae, foraminifera, corals, brachiopods, crinoids, sponges, gastropods and conodonts, and these extinctions occur approx. $2 \mathrm{~m}$ below the defined G-L GSSP level (Jin et al., 2006b; Kaiho et al., 2005). There is however significant debate regarding the nature and level of the mass extinction and different groups of fossils appear to have turnover at different levels with rugose coral and brachiopod extinctions occurring significantly before the step-wise extinctions of fusulinids, conodonts and ammonoids (Shen and Shi, 2009). Wignall et al. (2009a, 2009b) place the extinction interval, based on studies of the Gouchang section, central Guizhou, as equating with the upper $J$. 
shannoni and J. altudaensis conodont zones and hence as mid-Capitanian in age and immediately overlain by Emeishan LIP basalts. This proposed extinction level is different to the generally accepted one in the upper Capitanian. The age and duration of the Emeishan LIP basalts is poorly constrained but recent data using CA-TIMS (Shellnut et al., 2012; Zhong et al., 2014) suggests that volcanism spans the interval c. 260-259 Ma (latest Capitanian) rather than a mid-Capitanian age suggested by Wignall et al. (2009a, 2009b). Accepting a 260-259 Ma duration for the Emeishan LIP basalts and a G-L boundary age close to $259.1 \pm 0.5 \mathrm{Ma}$ as suggested by Zhong et al. (2014) a causative link between the Emeishan LIP and the Capitanian extinctions seen in China is inferred. Isozaki (2009) has suggested a link between the end-Guadalupian extinction and a superplume that triggered Pangean breakup. More equivocal is whether the extinction is global in nature and if it can be recognised in terrestrial sequences and at high latitudes. Recent data from the Karoo Supergroup, South Africa (Rubidge et al., 2013) provides a temporal framework for MiddleLate Permian vertebrate records in Gondwana. There appear to be no significant vertebrate extinctions in the Middle-Late Permian of the Karoo and the G-L boundary interval and Emeishan LIP equate with the Tropidostoma zone based on five high-resolution CA-TIMS dates of volcanic ashes. There appears to be no evidence for terrestrial or marine extinctions in southern hemisphere Gondwana related to the Emeishan LIP or low-latitude marine extinctions in the northern hemisphere. Proposed causative mechanisms (dramatic sea-level fall, volcanism, cooling) for the Capitanian extinctions appear to have affected only northern hemisphere low-latitude warm-climate biota. This brings into question the global nature of the Capitanian mass extinction.

\subsection{Global age of the end-Permian mass extinction: synchronous or diachronous?}


This is an author-produced, peer-reviewed version of this article. The final, definitive version of this document can be found online at Gondwana Research, published by Elsevier Copyright restrictions may apply. doi: 10.1016/j.gr.2014.09.002

The new high-precision geochronological data from Eastern Australia here presented supports an age close to $252 \mathrm{Ma}$ for the end-Permian mass extinction in nonmarine eastern Gondwana sequences. This indicates that the end-Permian mass extinction in Australia is essentially the same age in both terrestrial and marine sequences of high-latitude Gondwana and in low-latitude northern hemisphere marine and terrestrial sequences (Metcalfe et al, 2008; Shen et al., 2011). There appears to be little support for a diachronous end-Permian mass extinction (e.g. Wignall and Newton, 2003) with consequent constraints on causative mechanisms. Any proposed causative mechanism(s) for the end-Permian extinction must affect both marine and terrestrial environments in both high and low latitudes and over a short period of time. A global climate-change scenario involving combined multiple causative mechanisms, including massive volcanism (Siberian Traps), global warming (with global wildfires), methane release from clathrates, hypercapnia and oceanic anoxia and acidification, that occurred over a relatively short period of time (less than 0.5 my), is more likely than a single causative mechanism.

\subsection{Calibration of major climate-change}

FIGURE 17 ABOUT HERE

Previous attempts to internationally calibrate the age and duration of Permian glacial episodes in Australian Gondwana (Fielding et al., 2008a, 2008b, 2008c, 2010; Frank et al., 2008) have been hampered by the lack of reliable international calibration of eastern Australian sequences. This was due to endemic zonal schemes and lack of reliable radioisotopic age tie points and paucity of chemostratigraphical and magnetostritigraphical international calibration. Previous SHRIMP dating of tuffs in Eastern Australia are 
compromised by low precision and inaccuracy due to unreliable standards (see Section 3).

The new high-precision CA-TIMS ages for multiple tuffs in Eastern Australia here presented indicate that the age and duration of these glacial episodes needs revision.

The P3 glacial episode is identified in the Sydney Basin by glaciomarine deposits in the Wandrawandian Siltstone and Broughton Formation of the southern Sydney Basin (Fig. 13) and in the Branxton Formation and Mulbring Siltstone of the Hunter Valley (Fig. 14) in the northern Sydney Basin (Thomas et al., 2007; Fielding et al., 2008a, 2008b, 2008c). Fielding et al. (2008a) suggested that this glacial episode was 273-268 Ma: late Kungurian to latest Roadian in age. Our new CA-TIMS dates require the age and ageduration of this glacial episode to be revised. Our date for the top Broughton Formation in the southern Sydney Basin of 263.51 \pm 0.05 Ma constrains the age of the top of P3 close to 263.5 Ma (Fig. 13) which is consistent with its level at the top of the Mulbring Siltstone dated at c. 263 Ma by interpolation between our dates for the Jerrys Plains Sub-Group and Rowan Formation in the northern Sydney Basin (Fig. 14). The base of P3 is constrained close to 271 Ma based on our date of $271.60 \pm 0.08 \mathrm{Ma}$ from near the top of the Rowan Formation. Based on our new CA-TIMS ages, the P3 glacial episode ranges from c. 271-263.5 Ma (early Roadian to early Capitanian in age in terms of current international timescales) and has a duration of c. 7.5 million years. The age of $\mathrm{P} 3$ is thus significantly younger than previously interpreted and slightly longer duration than the previously interpreted 6 million years.

The P4 glaciation is recorded by glaciomarine facies and glendonites in some formations of the Illawarra Coal Measures in the southern Sydney Basin (Fielding et al., 2008a; Fig. 13) and correlatives in New South Wales (Diessel 1992; Fielding et al., 2008a; Fig. 14) and in the Freitag, Ingelara and Peawaddy Formations of the Bowen Basin, Queensland (Fielding et al., 2008a; Fig. 12). The youngest glacial facies in the Sydney Basin is recorded in the Newnes Formation of the Charbon Sub-group in the Western Coalfield 
(Fielding et al., 2008a). The top of the P4 glaciation is placed in the lower part of the Black Alley Shale in the Bowen Basin (Fielding et al., 2010; Fig. 12). The age of P4 was interpreted as 267-260 Ma: late Wordian to late Capitanian by Fielding et al. (2008a). The top of the P4 glaciation is here interpreted to be c. $254.5 \mathrm{Ma}$ (late Wuchiapingian) based on a series of new CA-TIMS dates in the Meeleebee 5 corehole in the southern Bowen Basin (Fig. 12) and on our date of $254.86 \pm 0.03$ Ma for the Huntley Claystone in the southern Sydney Basin (Fig. 13). The base of the P4 glaciation is placed at the base of the Erins Vale Formation by Fielding et al. (2008a) and this level is dated at c. 260 Ma based on our tuff ages in the Sydney Basin (Figs 13 and 14). The age of the P4 glaciation is interpreted here to be 260-254.5 Ma (late Capitanian to mid Wuchiapingian) which is significantly younger than the previously interpreted age, and to have a shorter duration of c. 5.5 million years compared to the previous estimate of 7 million years.

The package of strata showing no glacial related facies between P3 and P4 glacial episodes is estimated to represent approximately 3.5 million years, more than three times the previous estimate of c. 1 million years (Fielding et al., 2008a).

The P1 and P2 ice sheet glacial episodes, whilst not constrained by any new dates at this time, are interpreted as Asselian- early Sakmarian and late Sakmarian-early Artinskian respectively (Fielding et al., 2010) and the major phase of late Palaeozoic deglaciation in Gondwana occurred in the Artinskian-Kungurian.

A number of greenhouse (high CO2 levels) crises have been identified or interpreted in the Permian-Triassic sequences of Eastern Australia based on stomatal indices of seed ferns, sclerophylly of plants and isotopic composition of pedogenic carbonate in paleosols (Retallack, 2005, 2013; Retallack et al., 2011). The age and correlation of these greenhouse crises in Eastern Australia was underpinned by an inadequate temporal framework and tied to now out-dated international timescales. The use of SHRIMP dates 
This is an author-produced, peer-reviewed version of this article. The final, definitive version of this document can be found online at Gondwana Research, published by Elsevier Copyright restrictions may apply. doi: 10.1016/j.gr.2014.09.002

based on the unreliable SL13 standard (e.g. in Retallack et al., 2011) is considered untenable.

We here calibrate some of the identified greenhouse crises using new high-precision CA-

TIMS dates. We date the crisis identified in the uppermost Pebbley Beach and Rowan

Formations of the Sydney Basin as early middle Roadian (Figs 13 and 17) rather than basal

Roadian as indicated by Retallack (2013). We confirm a mid-Capitanian age for the crisis at the base of the Illawarra/Whittingham Coal Measures based on our date of 263.51 for the

Broughton Formation and this correlates with the short interglacial episode between P3 and P4 alpine glaciations (Figs 13 and 17). Greenhouse crises in the upper Illawarra/Newcastle Coal Measures and lower Narrabeen Group of the Sydney Basin (straddling the PermianTriassic boundary) are dated as upper Changhsingian-Induan, and in the upper Narrabeen Group/lower Hawksbury Sandstone dated as upper Olenekian, correspond to hot climatic peaks indicated by conodont oxygen isotope data following the post mass extinction global warming (see Fig. 17).

\section{Conclusions}

- The Capitanian-Wuchiapingian/Guadalupian-Lopingian boundary is located at the level of the Thirroul Sandstone in the Sydney Basin, corresponds to the middle of the P4 glacial episode, and is coincident with the Emeishan large igneous province and the major regression and low sea level stand at that time.

- The Wuchiapingian-Changhsingian boundary is interpreted to be at the level of the Kembla Sandstone in the southern Sydney Basin, within the middle part of the Newcastle (Wollombi) Coal Measures in the Newcastle and Hunter coalfields area of the northern Sydney Basin, and in the middle part of the Black Alley Shale of the southern Bowen Basin. 
- The Permian-Triassic boundary (GSSP level) is placed approximately at the level of the Scarborough Sandstone in the southern Sydney Basin and within the Sagittarius Sandstone (lower Rewan Group) in the Bowen Basin.

- The Induan-Olenekian boundary is interpreted to be within the Bulgo Sandstone of the Narrabeen Group in the southern Sydney Basin.

- The Olenekian-Anisian boundary is placed at the base of the Hawksbury Sandstone in the Sydney Basin.

- There appears to be no evidence for terrestrial or marine extinctions in southern hemisphere Gondwana related to the Emeishan LIP or low-latitude marine extinctions in the northern hemisphere. Proposed causative mechanisms (dramatic sea-level fall, volcanism, cooling) for the Capitanian extinctions appear to have only affected northern hemisphere low-latitude warm-climate biota.

- $\quad$ Our new CA-TIMS data suggests that the P3 glacial episode is c. 271-263.5 Ma (early Roadian to early Capitanian) in age, and the P4 glacial episode is 260-254.5 Ma (late Capitanian to mid Wuchiapingian) in age. The durations of P3 and P4 glacial episodes are estimated at 7.5 and 5.5. million years respectively.

- The isotope geochronological framework here presented allows new estimates for the ages of Permian-Triassic greenhouse crises in the Sydney Basin. The crisis in the uppermost Pebbly Beach and Rowan Formations of the Sydney Basin is dated as early mid Roadian 
This is an author-produced, peer-reviewed version of this article. The final, definitive version of this document can be found online at

rather than basal Roadian. A mid-Capitanian age for the crisis at the base of the

Illawarra/Wittingham Coal Measures is confirmed and this correlates with the short interglacial episode between P3 and P4 alpine glaciations. Greenhouse crises in the upper Illawarra/Newcastle Coal Measures and lower Narrabeen Group of the Sydney Basin (straddling the Permian-Triassic boundary) are dated as upper Changhsingian-Induan, and in the upper Narrabeen Group/lower Hawksbury Sandstone are dated as upper Olenekian, corresponding to hot post mass extinction climatic peaks indicated by conodont oxygen isotope data.

- The end-Permian mass extinction is essentially the same age in both terrestrial and marine sequences of high-latitude Gondwana and in low-latitude northern hemisphere marine and terrestrial sequences.

- A global climate-change scenario for the end-Permian mass extinction, involving combined multiple causative mechanisms, including massive volcanism (Siberian Traps), global warming (with global wildfires), methane release from clathrates, hypercapnia and oceanic anoxia and acidification, that occurred over a relatively short period of time (less than $0.5 \mathrm{my}$ ), is more likely than a single causative mechanism.

\section{Acknowledgements}

We thank the New South Wales Geological Survey for access to borehole cores and for permission to sample these. We also thank Centennial Coal, Origin Energy, Peabody Energy, and Xstrata for provision of core material and other data and for facilitating the sampling of tuffs. The project was financially supported by an Australian Research Council Discovery 
This is an author-produced, peer-reviewed version of this article. The final, definitive version of this document can be found online at

Project Grant DP109288, by a research grant from Centennial Coal, and by Geoscience

Australia. We would like to thank Daniel Mantle, Simon Bodorkos, Kieth Sircombe, Rob

Willink, Malcolm Ives, Brian Jones, Paul Carr, Robyn Purcell, Michael Creech, Shane

Kornek, Clinton Foster, John Laurie, Kevin Ruming, Kim Bayly, Shayne Kneen, Erin

Holmes, Chris Knight, Jamie Walters, Larissa Polachacz, Brent McInnes and Ron Bush for information and discussions and help with tuff sampling. We thank Chris Fielding and M.

Santosh for their helpful reviews of the manuscript.

\section{References}

Angiolini, L., (Ed), 2014. Permian Timescale. Permophiles 59, 38.

Benton, M.J., 1995. Diversification and extinction in the history of life. Science 268, 52-58.

Benton, M. J., Newell, A. J., 2014. Impacts of global warming on Permo-Triassic terrestrial ecosystems. Gondwana Research 25, 1308-1337.

Berner, R.A., 2002. Examination of hypotheses for the Permo-Triassic boundary extinction by carbon cycle modeling. Proceedings of the National Academy of Sciences, U.S.A. $99,4172-4177$.

Birgenheier, L.P., Frank, T.D., Fielding, C.R., Rygel, M.C., 2010. Coupled carbon isotopic and sedimentological records from the Permian system of eastern Australia reveal the response of atmospheric carbon dioxide to glacial growth and decay during the late Paleozoic Ice Age. Palaeogeography, Palaeoclimatology, Palaeoecology 286, 178193. 
This is an author-produced, peer-reviewed version of this article. The final, definitive version of this document can be found online at Gondwana Research, published by Elsevier Copyright restrictions may apply. doi: 10.1016/j.gr.2014.09.002

Black, L.P., Jagodzinsky, E.A., 2003. Importance of establishing sources of uncertainty for the derivation of reliable SHRIMP ages. Australian Journal of Earth Sciences 50, 503 512.

Black, L.P. Kamo, S.L., Williams, I.S., Mundil, R., Davis, D.W., Korsch, R.J., Foudoulis, C., 2003. The application of SHRIMP to Phanerozoic geochronology; a critical appraisal of four zircon standards. Chemical Geology 200, 171-188.

Black, L.P. Kamo, S.L., Allen, C.M., Davis, D.W., Aleinikoff, J.N., Valley, J.W., Mundil, R., Campbell, I.H., Korsch, R.J. Williams, I.S., Foudoulis, C., 2004. Improved $206 \mathrm{~Pb} / 238 \mathrm{U}$ microprobe geochronology by the monitoring of a trace-element-related matrix effect; SHRIMP, ID-TIMS, ELA-ICP-MS and oxygen isotope documentation for a series of zircon standards. Chemical Geology 205, 115-140.

Bodorkos, S., Crowley, J., Metcalfe, I., Nicoll, R.S., Sircombe, K., 2012. Best of both worlds: combining SHRIMP and CA-TIMS methods in refining geochronological determinations for timescale calibration. In: Kositcin, N., Bodorkos, S. (Eds) 6th International SHRIMP Workshop - Program and Abstracts. Record 2012/52, Geoscience Australia, Canberra, 21-24.

Boyd, R., Leckie, D., 2000. Greta Coal Measures in the Muswellbrook Anticline area, New South Wales. Australian Journal of Earth Sciences 47, 259-279.

Briggs, D.J.C., 1998. Permian Productidina and Strophalosiidina from the Sydney-Bowen Basin and New England Orogen: systematics and biostratigraphic significance. Association of Australasian Palaeontologists, Memoir 19, 1-258.

Burgess, S.D., Bowring, S., Shen, S-z., 2014. High-precision timeline for Earth's most severe extinction. PNAS Early Edition, www.pnas.org/cgi/doi/10.1073/pnas.1317692111.

Carr, P.F., Fanning,M., Jones, B.G., Hutton, A.C., 2003. Geochronology of coal measures in the Sydney Basin from U-Pb SHRIMP dating of airfall tuffs. In: Hutton, A.C., Jones, 
B.G., Carr, P.F., Ackerman, B., Switzer, A.D. (Eds.), 35th Sydney Basin Symp. Univ. Wollongong Proc., 303-305.

Chen, B., Joachimski, M.M., Sun, Y., Shen, S-Z., Lai, X., 2011. Carbon and conodont apatite oxygen isotope records of Guadalupian-Lopingian boundary sections: Climatic or sea-level signal? Palaeogeography, Palaeoclimatology, Palaeoecology 311, 145-153.

Clapham, M.E., Shen, S-z., Bottjer, D.J., 2009. The double mass extinction revisited: reassessing the severity, selectivity, and causes of the end-Guadalupian biotic crisis (Late Permian). Paleobiology 35, 32-50.

Collins, S., 2009. High stand or low stand: A geochemical and petrological insight into the cyclicity and depositional environment of the Wallabella Coal Member, Tinowon Formation, Bowen Basin. Unpublished Honours Thesis, The University of Queensland.

Condon D.J., Schoene R.B, McLean N.M., Bowring S.A., Parrish R, Noble S.R., (in prep) Calibration of the EARTHTIME 235U-233U-205Pb-(202Pb) tracer for high-precision $\mathrm{U} / \mathrm{Pb}$ geochronology: Part I, Metrology and traceability, for submission to Geochemistry Geophysics Geosystems.

Crapp, C.E., Nolan, R., 1975. Newcastle district. In: Traves, D.M., King, D. Ž (Eds), Economic Geology of Australia and Papua New Guinea-2: Coal. Australian Institute of Mining and Metallurgy, Monograph 6, 163-175.

Creech M.K., Ives M., Stevenson D., Brunton J., Rigby R., Leary S., Graham P., Smith C., Atkins B., Knight C., Salter G., 2004. A revision of the stratigraphy of the Wollombi Coal Measures. New South Wales Geological Survey Report GS2004 415.

Crowley, J.L., Schoene, B., Bowring, S.A., 2007. U-Pb dating of zircon in the Bishop Tuff at the millennial scale: Geology 35, 1123-1126.

Diessel, C.F.K., 1992. Coal-Bearing Depositional Systems. Springer, Berlin. 
This is an author-produced, peer-reviewed version of this article. The final, definitive version of this document can be found online at Gondwana Research, published by Elsevier Copyright restrictions may apply. doi: 10.1016/j.gr.2014.09.002

Draper, J. J., Fielding, C. R., Roberts, J., Claoué-long, J. C., Foster, C. B., 1997. SHRIMP zircon dating of the Permian system of eastern Australia, Discussion and Reply. Australian Journal of Earth Sciences 44, 535-538.

Eyles, N., Mory, A.J., Backhouse, J., 2002. Carboniferous-Permian palynostratigraphy of west Australian marine rift basins: resolving tectonic and eustatic controls during Gondwanan glaciations. Palaeogeography, Palaeoclimatology, Palaeoecology 184, 305-319.

Fielding, C.R., Frank, T.D., Birgenheier, L.P., Rygel, M.C., Jones, A.T., Roberts, J., 2008 a. Stratigraphic imprint of the Late Paleozoic Ice Age in eastern Australia: a record of alternating glacial and nonglacial climate regime. Geological Society of London Journal 165, 129-140.

Fielding, C.R., Frank, T.D., Isbell, J.L., 2008b. The Late Paleozoic Ice Age - a review of current understanding and synthesis of global climate patterns. In: Fielding, C.R., Frank, T.D., Isbell, J.L. (Eds.), Resolving the Late Paleozoic Ice Age in Time and Space: Geological Society of America Special Publication 441, 343-354.

Fielding, C.R., Frank, T.D., Birgenheier, L.P., Rygel, M.C., Jones, A.T., Roberts, J., 2008 c. Stratigraphic record and facies associations of the late Paleozoic ice age in eastern Australia (New South Wales and Queensland). In: Fielding, C.R., Frank, T.D., Isbell, J.L. (Eds.), Resolving the Late Paleozoic Ice Age in Time and Space: Geological Society of America Special Paper 441 41-58.

Fielding, C.R., Frank, T.D., Isbell, J.L., Henry, L.C., Domack, E.W., 2010. Stratigraphic signature of the late Palaeozoic Ice Age in the Parmeener Supergroup of Tasmania, SE Australia, and inter-regional comparisons. Palaeogeography, Palaeoclimatology, Palaeoecology 298, 70-90. 
This is an author-produced, peer-reviewed version of this article. The final, definitive version of this document can be found online at Gondwana Research, published by Elsevier Copyright restrictions may apply. doi: 10.1016/j.gr.2014.09.002

Foster, C.B., Archbold, N.W., 2001. Chronologic anchor points for the Permian and Early Triassic of the Eastern Australian basins. In: Weiss, R.H. (Ed.), Contributions to the Geology and Paleontology of Gondwana in Honour of Helmut Wopfner. Geological Institute, University of Cologne, pp. 175-197.

Foster C. B., Logan G. A., Summons R. E., 1998. The Permian-Triassic boundary in Australia: where is it and how is it expressed? Proceedings of the Royal Society of Victoria 110, $247-266$.

Frank, T.D., Birgenheier, L.P., Montanez, I.P., Fielding, C.R., Rygel, M.C., 2008. Controls on late Paleozoic climate revealed by comparison of near-field stratigraphic and farfield stable isotopic records. In: Fielding, C.R., Frank, T.D., Isbell, J.L. (Eds.), Resolving the Late Paleozoic Ice Age in Time and Space: Geological Society of America Special Paper 441, 331-342.

Galfetti, T., Bucher, H., Ovtcharova, M., Schaltegger, U., Brayard, A., Bruhwiler, T., Goudemand, N., Weissert, H., Hochuli, P.A., Cordey, F., Guodun, K., 2007. Timing of the Early Triassic carbon cycle perturbations inferred from new $\mathrm{U}-\mathrm{Pb}$ ages and ammonoid biochronozones. Earth and Planetary Science Letters 258, 593-604.

Gerstenberger, H., Haase, G., 1997. A highly effective emitter substance for mass spectrometric $\mathrm{Pb}$ isotope ratio determinations. Chemical Geology 136, 309-312.

Gorter, J.D., Nicoll, R.S., Metcalfe, I., Willink, R.J., Ferdinando, D., 2009. The PermianTriassic boundary in western Australia: evidence from the Bonaparte and Northern Perth basins: exploration implications. Australian Petroleum Production \& Exploration Association Journal 2009, 311-336.

Goudemand, N., Romano, C., Brayard, A., Hochuli, P. A., Bucher, H., 2013. Comment on "Lethally Hot Temperatures During the Early Triassic Greenhouse". Science 339, 1033-c. 
This is an author-produced, peer-reviewed version of this article. The final, definitive version of this document can be found online at Gondwana Research, published by Elsevier Copyright restrictions may apply. doi: 10.1016/j.gr.2014.09.002

Gradstein, F.M., Ogg, J.G., Schmitz, M.D., Ogg, G.M., 2012. The Geologic Time Scale 2012. Amsterdam, Elsevier.

Grice K., Cao C., Love G. D., Bottcher M. E., Twitchett R. J., Grosjean E., Summons R. E., Turgeon S. C., Dunning W., Jin Y., 2005. Photic zone euxinia during the Permian Triassic Superanoxic Event. Science 307, 706 - 709.

Gulson B., Diessel C. F. K., Mason D. R., Krogh T. E., 1990. High precision radiometric ages from the northern Sydney Basin and their implication for the Permian time interval and sedimentation rates. Australian Journal of Earth Sciences 37, 459-469.

Hansen, H.J. Lojen, S., Toft, P., Dolenec, T. Tong, J., Michaelsen, P., Sarkar, A., 2000. Magnetic susceptibility and organic carbon isotopes of sediments across some marine and terrestrial Permo-Triassic boundaries. In: Yin, H., Dickins, J.M., Shi, G.R., Tong, J. (Eds) Permian-Triassic Evolution of Tethys and Western Circum-Pacific. Cambridge University Press, 271-289.

Henderson, C.M., Davydov, V.I., Wardlaw, B.R., Gradstein, F.M., Hammer, O., 2012. The Permian Period. In: Gradstein, F.M., Ogg, J.G., Schmitz, M.D., Ogg, G.M., (Eds) The Geologic Time Scale 2012. Amsterdam, Elsevier, 653-679.

Herbert, C., 1997. Relative sea level control of deposition in the Late Permian Newcastle Coal Measures of the Sydney Basin, Australia. Sedimentary Geology 107, 167- 187. Huang, C., Tong, J., Hinnov, L., Chen, Z.Q., 2011. Did the great dying of life take 700 k.y.? Evidence from global astronomical correlation of the Permian-Triassic boundary interval. Geology 39, 779-782.

Huyskens, M.H., Amelin, Y., Nicoll, R.S., Metcalfe, I., 2013. Indirect dating of the Guadalupian-Lopingian Boundary. Goldschmidt 2013 Conference Abstracts, 1349. The Mineralogical Society of Great Britain and Ireland. DOI:10.1180/minmag.2013.077.5.8 
Isozaki, Y., 2009. Illawarra Reversal: The fingerprint of a superplume that triggered Pangean breakup and the end-Guadalupian (Permian) mass extinction. Gondwana Research 15, $421-432$.

Isozaki, Y., Kawahata, H., Minoshima, K., 2007a. The Capitanian (Permian) Kamura cooling event: the beginning of the Paleozoic-Mesozoic transition. Palaeoworld 16, 16-30.

Isozaki, Y., Kawahata, H., Ota, A., 2007b. A unique carbon isotope record across the Guadalupian-Lopingian (Middle-Upper Permian) boundary in mid-oceanic paleoatoll carbonates: the high-productivity "Kamura event" and its collapse in Panthalassa. Global and Planetary Change 55, 21-38.

Ives, M., Brinton, J., Edwards, J., Rigby, R., Tobin, C., Weber, C.R., 1999. Revision of the stratigraphy of the Newcastle Coal Measures. Bulletin of the Coalfield geology Council of New South Wales 1, 113-119.

Jaffey, A.H., Flynn, K.F., Glendenin, L.E., Bentley, W.C., Essling, A.M., 1971. Precision measurements of half-lives and specific activities of 235U and 238U. Physical Review C 4, 1889-1906.

Jin, Y.G., Wang, Y., Wang, W., Shang, Q.H., Cao, C.Q., Erwin, D.H., 2000. Pattern of marine mass extinction near the Permian-Triassic boundary in South China. Science $289,432-436$.

Jin, Y., Shen, S-z., Henderson, C.M., Wang, X., Wang, W., Wang, Y., Cao, C., Shang, Q., 2006a. The Global Stratotype Section and Point (GSSP) for the boundary between the Capitanian and Wuchiapingian Stage (Permian). Episodes 29, 253-262.

Jin, Y.G., Wang, Y., Henderson, C., Wardlaw, B.R., Shen, S-Z., Cao, C., 2006b. The Global Boundary Stratotype Section and Point (GSSP) for the base of Changhsingian Stage (Upper Permian). Episodes 29, 175-182. 
This is an author-produced, peer-reviewed version of this article. The final, definitive version of this document can be found online at Gondwana Research, published by Elsevier Copyright restrictions may apply. doi: 10.1016/j.gr.2014.09.002

Joachimski, M.M., Lai, X., Shen, S., Jiang, H., Luo, G., Chen, J., Sun, Y., 2012. Climate warming in the latest Permian and the Permian-Triassic mass extinction. Geology 40, 195-198.

Kaiho, K., Chen, Z-Q., Ohashia, T., Arinobuc, T., Sawadad, K., Cramer, B.S., 2005. A negative carbon isotope anomaly associated with the earliest Lopingian (Late Permian) mass extinction. Palaeogeography, Palaeoclimatology, Palaeoecology 223, 172-180.

Kamo, S.L., Czamanske, G.K., Krogh, T.E., 1996. A minimum U-Pb age for Siberian flood basalt volcanism. Geochimica et Cosmochimica Acta 60, 3505-3511.

Kamo, S.L., Czamanske, G.K., Amelin, Y., Fedorenko, V.A., Davis, D.W., Trofimov, V.R., 2003. Rapid eruption of Siberian flood-volcanic rocks and evidence for coincidence with the Permian-Triassic boundary and mass extinction at $251 \mathrm{Ma}$. Earth and Planetary Science Letters 214, 75-91.

Korsch, R. J., Totterdell, J. M., 2009. Subsidence history and basin phases of the Bowen, Gunnedah and Surat Basins, eastern Australia. Australian Journal of Earth Sciences $56,335-353$.

Korsch, R. J., Totterdell, J. M., Cathro, D. L., Nicoll, M. G., 2009. Early Permian East Australian Rift System. Australian Journal of Earth Sciences 56, 381-400.

Korte, C., Jasper, T., Kozur, H.W., Veizer, J., 2005a. $\delta 180$ and $\delta 13 \mathrm{C}$ of Permian brachiopods: a record of seawater evolution and continental glaciation. Palaeogeography, Palaeoclimatology, Palaeoecology 224, 333-351.

Korte, C., Kozur, H.W., Veizer, J., 2005b. $\delta 13 \mathrm{C}$ and $\delta 18 \mathrm{O}$ values of Triassic brachiopods and carbonate rocks as proxies for coeval seawater and palaeotemperature. Palaeogeography, Palaeoclimatology, Palaeoecology 226, 287-306. 
This is an author-produced, peer-reviewed version of this article. The final, definitive version of this document can be found online at Gondwana Research, published by Elsevier Copyright restrictions may apply. doi: 10.1016/j.gr.2014.09.002

Korte, C., Jones, P.J., Brand, U., Mertmann, D., Veizer, J., 2008. Oxygen isotope values from high-latitudes: Clues for Permian sea-surface temperature gradients and Late Palaeozoic deglaciation. Palaeogeography, Palaeoclimatology, Palaeoecology 269, 116.

Krogh, T.E., 1973. A low contamination method for hydrothermal decomposition of zircon and extraction of $\mathrm{U}$ and $\mathrm{Pb}$ for isotopic age determination. Geochimica et Cosmochimica Acta 37, 485-494.

Kryza, R., Crowley, Q.G., Larionov, A., Pin, C., Oberc-Dziedzic, T., Mochnacka, K., 2012. Chemical abrasion applied to SHRIMP zircon geochronology: An example from the Variscan Karkonosze Granite (Sudetes, SW Poland). Gondwana Research 21, 757767.

Liu, X-c., Wang, W., Shen, S-z., Gorgij, M.N., Ye, F-c., Zhang, Y-c., Furuyama, S., Kano, A., Chen, X-z., 2013. Late Guadalupian to Lopingian (Permian) carbon and strontium isotopic chemostratigraphy in the Abadeh section, central Iran. Gondwana Research $24,222-232$.

Ludwig, K.R., 2003. User's Manual for Isoplot 3.00. Berkeley Geochronology Center: Berkeley, CA, 70 p.

Mattinson, J.M., 2005. Zircon U-Pb chemical abrasion ("CA-TIMS") method: combined annealing and multi-step partial dissolution analysis for improved precision and accuracy of zircon ages. Chemical Geology 220, 47-66.

McInnes, B.I.A., Evans, N.J., Danišík, M., Williams, I.S., McDonald, B.J., Collins, S., Golding, S., Esterle, J., Willink, R., 2010. Time-temperature history of the Permian Tinowon Formation coal seam gas reservoir revealed by integrated $\mathrm{U}-\mathrm{Th}-\mathrm{Pb}-\mathrm{He}$ and fission track techniques. Australian Earth Science Convention 2010, Geological Society of Australia Abstracts No. 98, 387. 
This is an author-produced, peer-reviewed version of this article. The final, definitive version of this document can be found online at Gondwana Research, published by Elsevier Copyright restrictions may apply. doi: 10.1016/j.gr.2014.09.002

McLean, N.M., Condon, D.J., Schoene, R.B., Bowring, S.A., (in prep). Calibration of the EARTHTIME 235U-233U-205Pb-(202Pb) tracer for high-precision $\mathrm{U} / \mathrm{Pb}$ geochronology: Part II, Evaluating Analytical and Systematic Uncertainties, for submission to Geochemistry Geophysics Geosystems.

Metcalfe, I., 2013. Gondwana dispersion and Asian accretion: tectonic and palaeogeographic evolution of eastern Tethys. Journal of Asian Earth Sciences 66, 1-33.

Metcalfe, I., Nicoll, R.S., Willink, R.J., 2008. Conodonts from the Permian Triassic transition in Australia and position of the Permian-Triassic boundary. Australian Journal of Earth Sciences 55, 349-361.

Michaelsen P., 2002. Mass extinction of peat-forming plants and the effect on fluvial styles across the Permian - Triassic boundary, northern Bowen Basin, Australia. Palaeogeography, Palaeoclimatology, Palaeoecology 179, 173 - 188.

Morante R., 1995. Permian - Triassic stable isotope stratigraphy of Australia. PhD thesis, Macquarie University, Sydney (unpubl.).

Morante R., 1996. Permian and early Triassic isotopic records of carbon and strontium in Australia and a scenario of events about the Permian - Triassic boundary. Historical Biology 11, 289-310.

Morante R., Herbert C., 1994. Carbon isotopes and the sequence stratigraphy about the Permian/Triassic boundary in the Sydney Basin. In: Proceedings of the 28th Newcastle Symposium on Advances in the Study of the Sydney Basin, pp. $102-109$. Department of Geology University of Newcastle Publication 606.

Morante R., Veevers J. J., Andrew A. S., Hamilton P. J., 1994. Determination of the Permian - Triassic boundary in Australia from carbon isotope stratigraphy. APEA Journal 34, $330-336$. 
This is an author-produced, peer-reviewed version of this article. The final, definitive version of this document can be found online at Gondwana Research, published by Elsevier Copyright restrictions may apply. doi: 10.1016/j.gr.2014.09.002

Mundil, R., Ludwig, K.R., Metcalfe, I., Renne, P.R., 2004. Age and timing of the Permian mass extinctions: $\mathrm{U} / \mathrm{Pb}$ geochronology on closed-system zircons. Science 305, 1760 1763.

Mundil, R., Metcalfe, I., Chang, S., Renne, P.R., 2006. The Permian-Triassic boundary in Australia: New radio-isotopic ages. P. A436 in, 16th Goldscmidt Conference Melbourne, Awards ceremony speeches and abstracts. Geochimica et Cosmochimica Acta 70, Issue 18 Supplement 1.

Mundil, R., Palfy, J., Renne, P.R., Brack, P., 2010. The Triassic time scale: new constraints and a review of geochronological data. In: Lucas, S. G. (Ed.) The Triassic Timescale. Geological Society, London, Special Publications 334, 41-60.

Ovtcharova, M., Bucher, H., Schaltegger, U., Galfetti, T., Brayard, A., Guex, J., 2006. New Early to Middle Triassic U-Pb ages from South China: calibration with ammonoid biochronozones and implications for the timing of the Triassic biotic recovery. Earth and Planetary Science Letters 243, 463-475.

Powell, C.McA., 1996. Breakup and dispersal of the Rodinia supercontinent: implications for resource exploration. 13th Geological Convention, Canberra. Geol. Soc. Aust. Abstr. 41,351 .

Pratt, W., 1998. Gunnadah Coalfield: Notes to accompany the 1:100,000 scale Gunnedah Coalfield Regional Geology (North and South) Maps. Geological Survey of New South Wales Report GS1998/505.

Reichow, M.K., Pringle, M.S., Al'Mukhamedov, A.I., Allen, M.B., Andreichev, V.L., Buslov, M.M., Davies, C.E., Fedoseev, G.S., Fitton, J.G., Inger, S., Medvedev, A.Ya., Mitchell, C., Puchkov, V.N., Safonova, I. Yu., Scott, R.A., Saunders, A.D., 2009. The timing and extent of the eruption of the Siberian Traps large igneous province: 
Implications for the end-Permian environmental crisis. Earth and Planetary Science Letters 277, 9-20.

Renne, P.R., 1995. Excess 40Ar in biotite and hornblende from the Noril'sk 1 intrusion, Siberia: implications for the age of the Siberian Traps. Earth and Planetary Science Letters 131, 165-176.

Renne, P.R., Zichao, Z., Richards, M.A., Black, M.T., Basu, A.R., 1995. Synchrony and causal relations between Permian-Triassic boundary crises and Siberian flood volcanism. Science 269, 1413-1416.

Retallack, G.J., 1995. Permian-Triassic Life Crisis on Land. Science 26, 77-80.

Retallack, G.J., 1999. Post-apocalyptic greenhouse paleoclimate revealed by earliest Triassic paleosols in the Sydney Basin, Australia. Geological Society of America Bulletin 111, $52-70$.

Retallack, G.J., 2005. Permian greenhouse crises. In: Lucas, S.G. and Zeigler, K.E., (Eds), The Nonmarine Permian. New Mexico Museum of Natural History and Science Bulletin No. 30, 256-269.

Retallack, G.J., 2013. Permian and Triassic greenhouse crises. Gondwana Research 24, 90 103.

Retallack, G.J., Sheldon, N.D., Carr, P.F., Fanning, M., Thompson, C.A., Williams, M.L., Jones, B.G., Hutton, A., 2011. Multiple Early Triassic greenhouse crises impeded recovery from Late Permian mass extinction. Palaeogeography, Palaeoclimatology, Palaeoecology 308, 233-251.

Roberts J., Claoué-Long J. C., Jones P. J., 1995a. Australian Carboniferous Time. In Time Scales and Global Stratigraphic Correlation. SEPM Special Publication 54, 23-40.

Roberts J., Claoue-Long J. C., Jones P. J., Foster C. B., 1995b. SHRIMP zircon age control of Gondwanan sequences in Late Carboniferous and Early Permian Australia. In: 
Dunnay R. E., Hailwood E. A. (Eds) Dating and correlating biostratigraphically barren strata. Geological Society of London Special Publication 89, 145-174.

Roberts, J., Claoué-Long, J. C., Foster, C. B., 1996. SHRIMP zircon dating of the Permian System of eastern Australia. Australian Journal of Earth Sciences 43, 401-421.

Rubidge, B.S., Erwin, D.H., Jahandar Ramezani, Bowring, S.A., de Klerk, W.J., 2013. Highprecision temporal calibration of Late Permian vertebrate biostratigraphy: U-Pb zircon constraints from the Karoo Supergroup, South Africa. Geology 41, 363-366.

Schneebeli-Hermann, E., Kürschner, W.M., Hochuli, P.A., Ware, D., Weissert, H., Bernasconi, S.M., Roohi, G., ur-Rehman, K., Goudemand, N., Bucher, H., 2013.

Evidence for atmospheric carbon injection during the end-Permian extinction. Geology 41, 579-582.

Shellnutt, J.G., Denyszyn, S.W., Mundil, R., 2012. Precise age determination of mafic and felsic intrusive rocks from the Permian Emeishan large igneous province (SW China). Gondwana Research 22, 118-126.

Shen, S.-z., Shi, G.R., 2009. Latest Guadalupian brachiopods from the Guadalupian/Lopingian boundary GSSP section at Penglaitan in Laibin, Guangxi, South China and implications for the timing of the pre-Lopingian crisis. Palaeoworld $18,152-161$.

Shen, S.-z., Crowley, J.L., Wang, Y., Bowring, S.A., Erwin, D.H., Sadler, P.M., Cao, C.-q., Rothman, D.H., Henderson, C.M., Ramezani, J., Zhang, H., Shen, Y., Wang, X.-d., Wang, W., Mu, L., Li, W.-z., Tang, Y.-g., Liu, X.-1., Liu, L.-j., Zeng, Y., Jiang, Y.-f., Jin, Y.-g., 2011. Calibrating the end-Permian mass extinction. Science 334, 13671372.

Shen, S.-z., Cao, C.-q., Zhang, H., Bowring, S.A., Henderson, C.M., Payne, J.L., Davydov, V. Chen, B. Yuan, D-x., Zhang, Y-c., Wang, W., Zheng, Q-f., 2013. High-resolution 
$\delta 13$ Ccarb chemostratigraphy from latest Guadalupian through earliest Triassic in South China and Iran. Earth and Planetary Science Letters 375, 156-165.

Schmitz, M.D., Schoene, B., 2007. Derivation of isotope ratios, errors and error correlations for U-Pb geochronology using 205Pb-235U-(233U)-spiked isotope dilution thermal ionization mass spectrometric data: Geochemistry, Geophysics, Geosystems (G3) 8, Q08006, doi:10.1029/2006GC001492.

Stacey, J.S., Kramers, J.D., 1975. Approximation of terrestrial lead isotope evolution by a two-stage model. Earth and Planetary Science Letters 26, 207-221.

Tadros N.Z., 1999. Permian stratigraphy of the Gunnedah Basin. Coalfield Geology Council of New South Wales, Bulletin 1, 40-93.

Thomas B. M., Willink R. J., Grice K., Twitchett R. J., Purcell R. R., Archbold N. W., George A. D., Tye S., Alexander R., Foster, C. B., Barber C. J., 2004. Unique marine Permian - Triassic boundary section from Western Australia. Australian Journal of Earth Sciences 51, 423-430.

Thomas, S.G., Fielding, C.R., Frank, T.D., 2007. Lithostratigraphy of the Mid- Permian Wandrawandian Siltstone, southern Sydney Basin, New South Wales, Australia: record of glaciation and onset of the Hunter-Bowen Event? Australian Journal of Earth Sciences 54, 1057-1071.

Wang, W., Cao, C.Q., Wang, Y., 2004. The carbon isotope excursion on GSSP candidate section of Lopingian-Guadalupian boundary. Earth and Planetary Science Letters $220,57-67$.

Waschbuscha, P., Korsch, R. J., Beaumonta, C., 2009. Geodynamic modelling of aspects of the Bowen, Gunnedah, Surat and Eromanga Basins from the perspective of convergent margin processes. Australian Journal of Earth Sciences 56, 309-334. 
This is an author-produced, peer-reviewed version of this article. The final, definitive version of this document can be found online at Gondwana Research, published by Elsevier Copyright restrictions may apply. doi: 10.1016/j.gr.2014.09.002

Warren, A., 1997. A tetrapod fauna from the Permian of the Sydney Basin. Records of the Australian Museum 49, 25-33.

Wignall, P.B., Newton, R., 2003. Contrasting Deep-water Records from the Upper Permian and Lower Triassic of South Tibet and British Columbia: Evidence for a Diachronous Mass Extinction. PALAIOS 18, 153-167.

Wignall, P.B., Vedrine, S., Bond, D.P.G.,Wang,W., Lai, X.L., Ali, J.R., Jiang, H.S., 2009a. Facies analysis and sea-level change at the Guadalupian-Lopingian Global Stratotype (Laibin, South China), and its bearing on the end-Guadalupian mass extinction. Journal of the Geological Society 166, 655-666.

Wignall, P.B., Sun, Y.D., Bond, D.P.G., Izon, G., Newton, R.J., Vedrine, S., Widdowson, M., Ali, J.R., Lai, X., Jiang, H., Cope, H., Bottrell, S.H., 2009b. Volcanism, mass extinction, and carbon isotope fluctuations in the Middle Permian of China. Science $324,1179-1182$.

Williams, M.L., Jones, B.G., Carr, P.F., 2012. Geochemical consequences of the PermianTriassic mass extinction in a non-marine succession, Sydney Basin, Australia. Chemical Geology 326-327, 174-188.

Yan, D., Zhang, L., Qiu, Z., 2013. Carbon and sulfur isotopic fluctuations associated with the end-Guadalupian mass extinction in South China. Gondwana Research 24, 12761282.

Yin, H., Zhang, K., Tong, J., Yang, Z., Wu S., 2001. The Global Stratotype Section and Point (GSSP) of the Permian - Triassic boundary. Episodes 24, 102-114.

Zhong, Y-T., He, B., Mundil, R., Xu, Y-G., 2014. CA-TIMS zircon U-Pb dating of felsic ignimbrite from the Binchuan section: Implications for the termination age of Emeishan large igneous province. Lithos (in press) DOI: http://dx.doi.org/10.1016/j.lithos.2014.03.005 


\section{Figure and Table Captions}

Fig. 1. A: Palaeogeographic map for the Late Permian (260 Ma) showing the location of Australia at the eastern convergent margin of Gondwanaland facing the Panthalassan Ocean (after Powell 1996; Li \& Powell 2001; Waschbusch et al, 2009; Metcalfe, 2013). ARA = Arabia, PNG = Papua New Guinea, SWB = South West Borneo. B: Map of eastern Australia showing locations of Permian sedimentary basins (shaded green) and location of maps showing sample locations of Fig. 3 (red boxes).

Fig. 2. Comparison of SL13 standard based SHRIMP ages and uncertainties reported by Carr et al. (2003) and Retallack et al. (2011) compared to the CA-TIMS ages and uncertainties of this study using zircons plucked from the original SHRIMP mounts.

Fig. 3. Maps showing locations of dated tuff samples. A: Sydney Basin. B: Southern Bowen Basin. See Fig. 1B for regional geographic location.

Fig. 4. Stratigraphic section exposed in freeway cutting on the Great Southern Highway, Bulli Tops, near Wollongong (GPS S34 19.721 E 150 52.580) showing Bulli 5 and PCF17 sample horizon.

Fig. 5. Stratigraphic section of the Bulli Coal Seam in Excel Metropolitan DDH3 at Metropolitan Colliery (GPS S34.187047 E150.992334) showing the sampled tuff in the lower part of the Bulli Seam. 
This is an author-produced, peer-reviewed version of this article. The final, definitive version of this document can be found online at

Fig. 6. Stratigraphic interval in Centennial PN072 sampled for the Nobbys Tuff. The sampled interval in the upper part of the Nobbys Tuff is shown by boxed interval on core photo.

Fig. 7. Stratigraphic interval in Mandalong DDH95 sampled for the Awaba Tuff. The sampled interval in the upper part of the Awaba Tuff is shown by boxed interval on core photo.

Fig. 8. Stratigraphic sequence of the Upper Pilot, Fassifern and Great Northern Seams at Myuna and Mannering Collieries and stratigraphic position of the dated tuff Myuna 2 within the Great Northern Seam.

Fig. 9. Stratigraphic interval in Myuna DDH45 sampled for the Mannering Park Tuff. The sampled interval is shown by boxes on core photo.

Fig. 10. Sample horizons and GPS locations of dated samples M2, M3 and M4 from the Mangoola Mine (North Pit).

Fig. 11. Lithogical column for the Wallabella Coal Member of the Tinowon Formation in the Myall Creek 3 core hole showing the sampled tuff horizon. After Collins (2009).

Fig. 12. Sample locations and weighted mean U-Pb CA-TIMS ages of tuffs in the continuously cored Meeleebee 5 exploration well, southern Bowen Basins. Plots show individual zircons (red) used in weighted mean calculation and rejected zircon ages (blue). Uncertainties are $2 \sigma$ internal. The Wuchiapingian-Changhsingian stage boundary is unequivocally placed in the middle part of the Black Alley Shale. The important Mantuan 
Productus Beds marine marker horizon and upper part of the P4 glacial episode (Fielding et al., 2008a) are also shown.

Fig. 13. Weighted mean U-Pb CA-TIMS ages of tuffs in the southern Sydney Basin. Plots show individual zircons (red) used in weighted mean calculation and rejected zircon ages (blue). Uncertainties are $2 \sigma$ internal. Formation thicknesses are average values. PermianTriassic timescale compiled from Mundil et al. (2004), Ovtcharova et al. (2006), Lehrmann et al. (2006), Galfetti et al. (2007), Mundil et al. (2010), Shen et al. (2010), Shen et al. (2011), and Gradstein et al. (2012). Glacial phases from Fielding et al. (2008), greenhouse crises from Retallack et al. (2011) and Retallack (2013), carbon isotope curves for the Wuchiapingian from Birgenheier et al. (2010) and for the late Changhsingian from Williams et al. (2012). Age ranges of Siberian Traps and Emeishan volcanism from Renne (1995), Renne et al. (1995), Reichow et al. (2009) Kamo et al. (1996, 2003), Mundil et al. (2004), Shellnut et al. (2012) and Zhong et al. (in press).

Fig. 14. New high precision CA-TIMS weighted mean ages of tuffs plotted against representative stratigraphies for the Newcastle Coal Measures in the Newcastle coal field (Crapp and Nolan, 1975; Ives et al., 1999) and Hunter coal field (Creech et al., 2004) and generalized Permian-Early Triassic stratigraphy for the Hunter coal field (Tadros, 1999). Age uncertainties are $2 \sigma$ internal. Red bars are zircons included in the weighted mean calculation, blue bars are zircons interpreted to be inherited or detrital or to still exhibit lead loss. Permian timescale compiled from Mundil et al. (2004), Shen et al. (2010), Shen et al. (2011), Gradstein et al. (2012) and Zhong et al (in press). 
Fig. 15. Palynomorph and megaplant zones, leaf plant diversity and affinities, and peatforming plant abundance in the late Permian-middle Triassic of the Sydney and Bowen basins, Eastern Australia. The late Changhsingian mass extinction level and interpreted position of the GSSP-defined Permian-Triassic boundary and the new high-precision U-Pb tuff dates from the Sydney Basin at this level are also shown. U-Pb tuff date for the top Bandanna Formation is from Mundil et al. (2006). Partly after Retallack (1995) and Michaelesen (2002).

Fig. 16. Late Permian-Early Triassic $\delta^{13} \mathrm{C}_{\text {org }}$ data and palynozones for the Perth, Canning and Bonaparte basins, Western Australia and the Sydney and Bowen basins, Eastern Australia. The late Changhsingian mass extinction interval corresponds to the marked negative $\delta^{13} \mathrm{C}_{\text {org }}$ excursion which occurs in the P. microcorpus palynozone. Stable carbon isotope data are from Morante and Herbert (1994), Morante et al. (1994), Morante (1995, 1996) Hansen et al. (2000), Thomas et al. (2004), Grice et al. (2005) and Williams et al. (2012).

Fig. 17. Chronostratigraphic calibration and correlation of eastern Australian Permian-Early Triassic sequences, carbon and oxygen isotope records, sea-surface temperature variations, glacial episodes, sea-level changes, large igneous province (LIP) volcanism and magnetostratigraphy. Geological timescale from Gradstein et al. (2012). Glacial stages modified after Fielding et al. (2008a). Carbon isotopes for Sydney Basin from Birgenheier et al. (2010); for Shangsi, China from Shen et al. (2013); and for the Bowen Basin from Morante (1996). Oxygen isotopes and interpreted sea-surface temperatures for carbonate of brachiopod shells from Korte et al. (2005a, 2005b, 2008) and for apatite of conodonts from Goudeman et al. (2013). Greenhouse crises after Retallack (2005) and Retallack et al. (2011). 
Sea-level transgression-regression cycles and magnetostratigraphy from Henderson et al.

(2012) and Ogg (2012).

Table 1. Tuff sample locality details.

Table 2. Weighted mean dates interpreted as depositional ages of tuff samples and uncertainties ( $\mathrm{x}$ is the internal error, $\mathrm{y}$ is the error including tracer calibration uncertainty, and $\mathrm{z}$ is the error including decay constant uncertainty). MSWD = Mean square weighted deviation. POF $=$ Probability of fit. See Figs 12, 13 and 14 for weighted mean age plots. 
This is an author-produced, peer-reviewed version of this article. The final, definitive version of this document can be found online at Gondwana Research, published by Elsevier Copyright restrictions may apply. doi: 10.1016/j.gr.2014.09.002
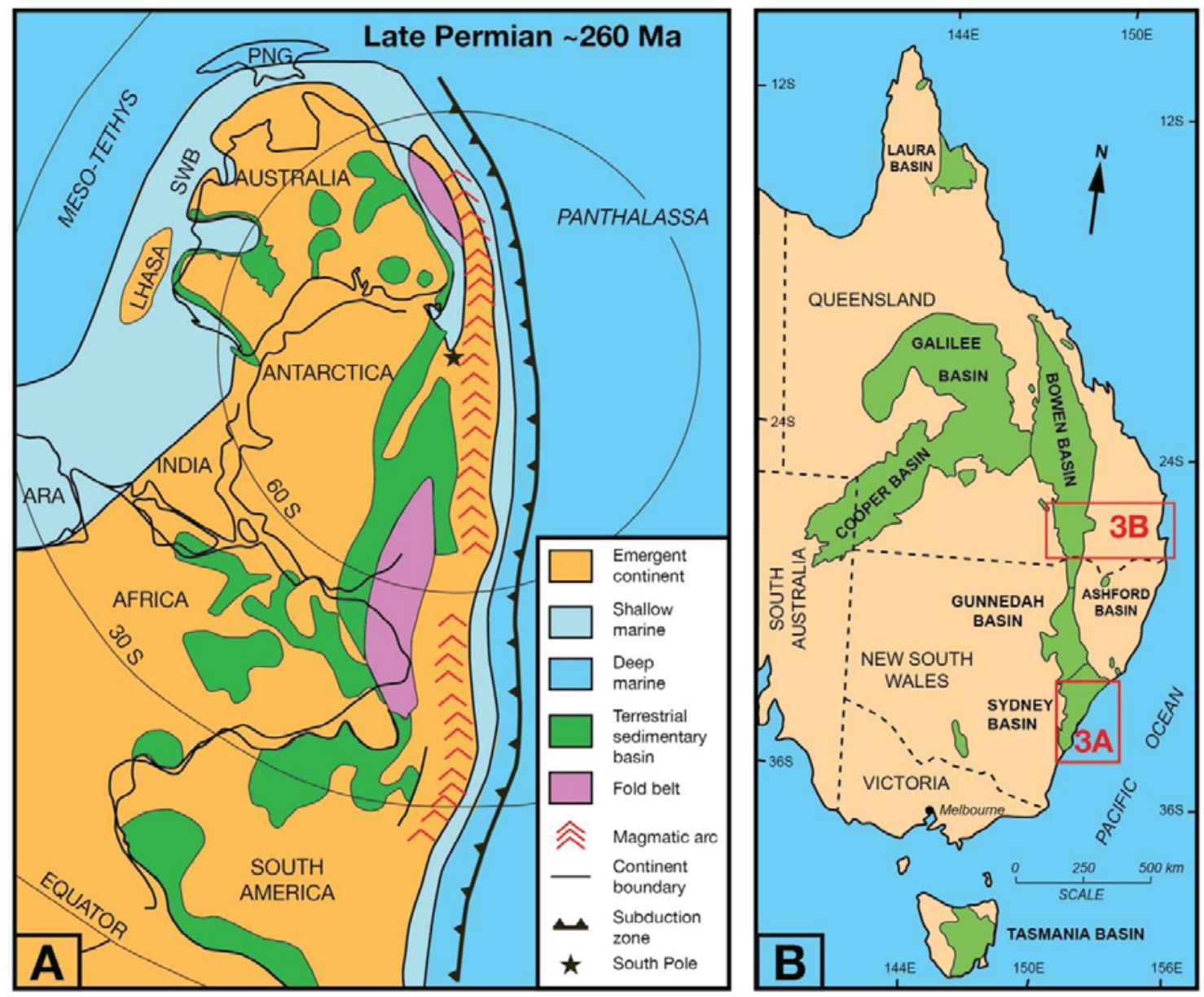

Figure 1 
This is an author-produced, peer-reviewed version of this article. The final, definitive version of this document can be found online at Gondwana Research, published by Elsevier Copyright restrictions may apply. doi: 10.1016/j.gr.2014.09.002

\begin{tabular}{|c|c|c|c|c|c|c|c|c|}
\hline 264 & - & & $\begin{array}{l}\text { D SHR } \\
-\mathrm{CA}-\mathrm{I}\end{array}$ & $\begin{array}{l}P-R \\
\text { IMS }\end{array}$ & $\begin{array}{l}\text { allack } \\
\text { his stu }\end{array}$ & $\begin{array}{l}\text { al. }(2 c \\
y\end{array}$ & & \\
\hline $\begin{array}{l}\sum_{\substack{\mathbb{\sigma} \\
\Phi}}^{260} 256 \\
252\end{array}$ & $\stackrel{\circ}{\frac{0}{0}}$ & $\stackrel{\infty}{\frac{\infty}{U}}$ & 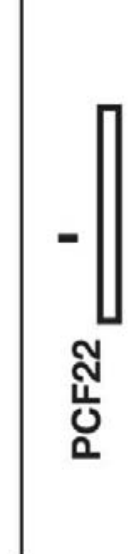 & 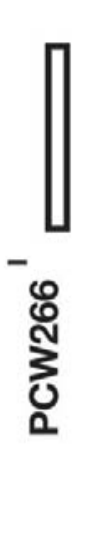 & 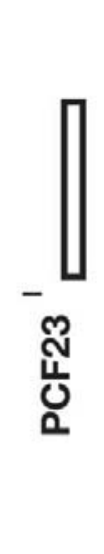 & 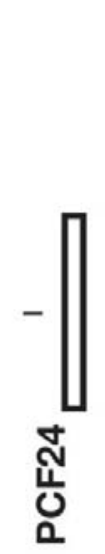 & స్లై & 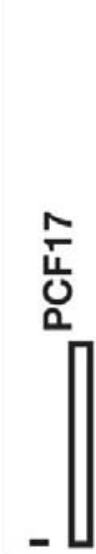 \\
\hline
\end{tabular}

Figure 2 

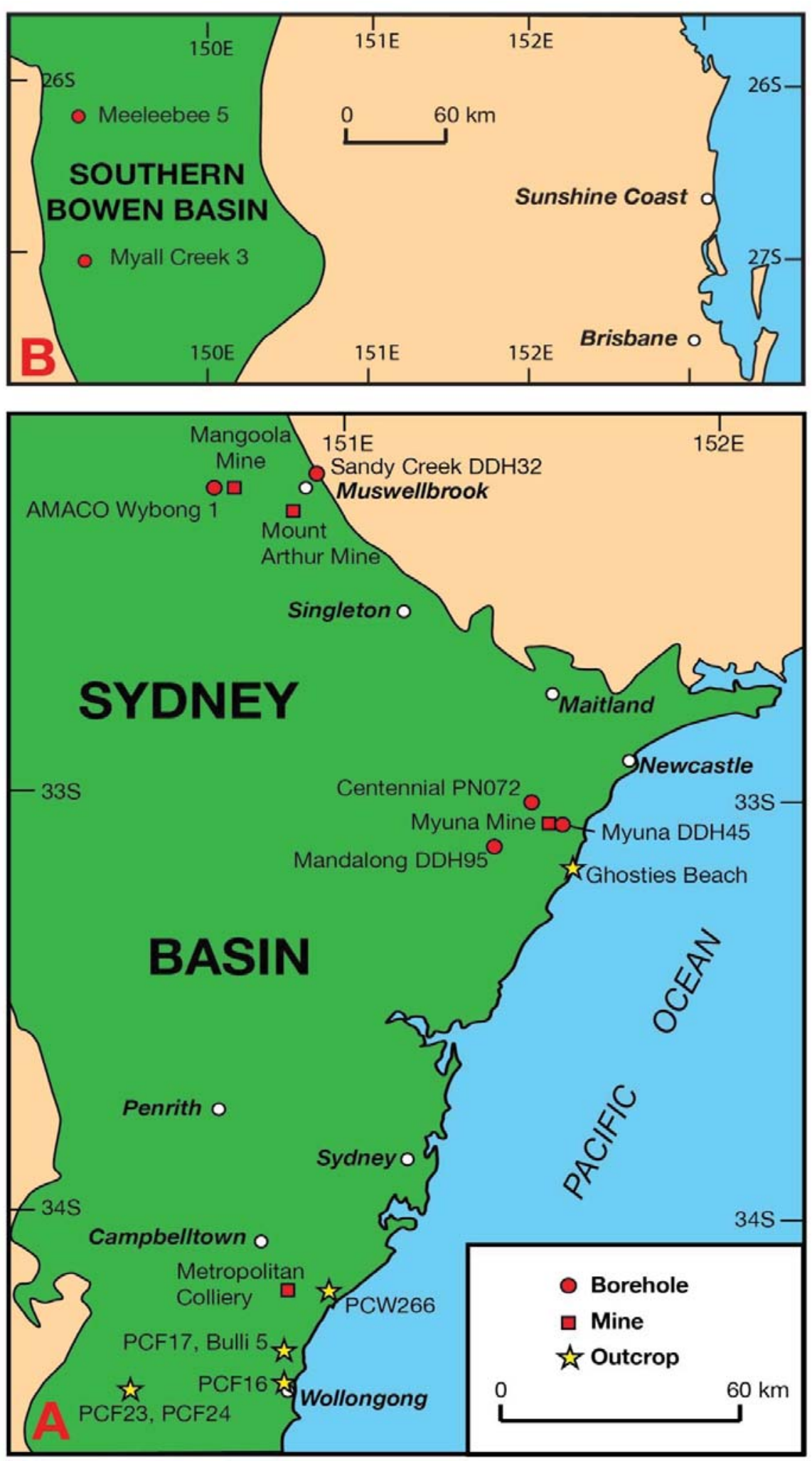

Figure 3 


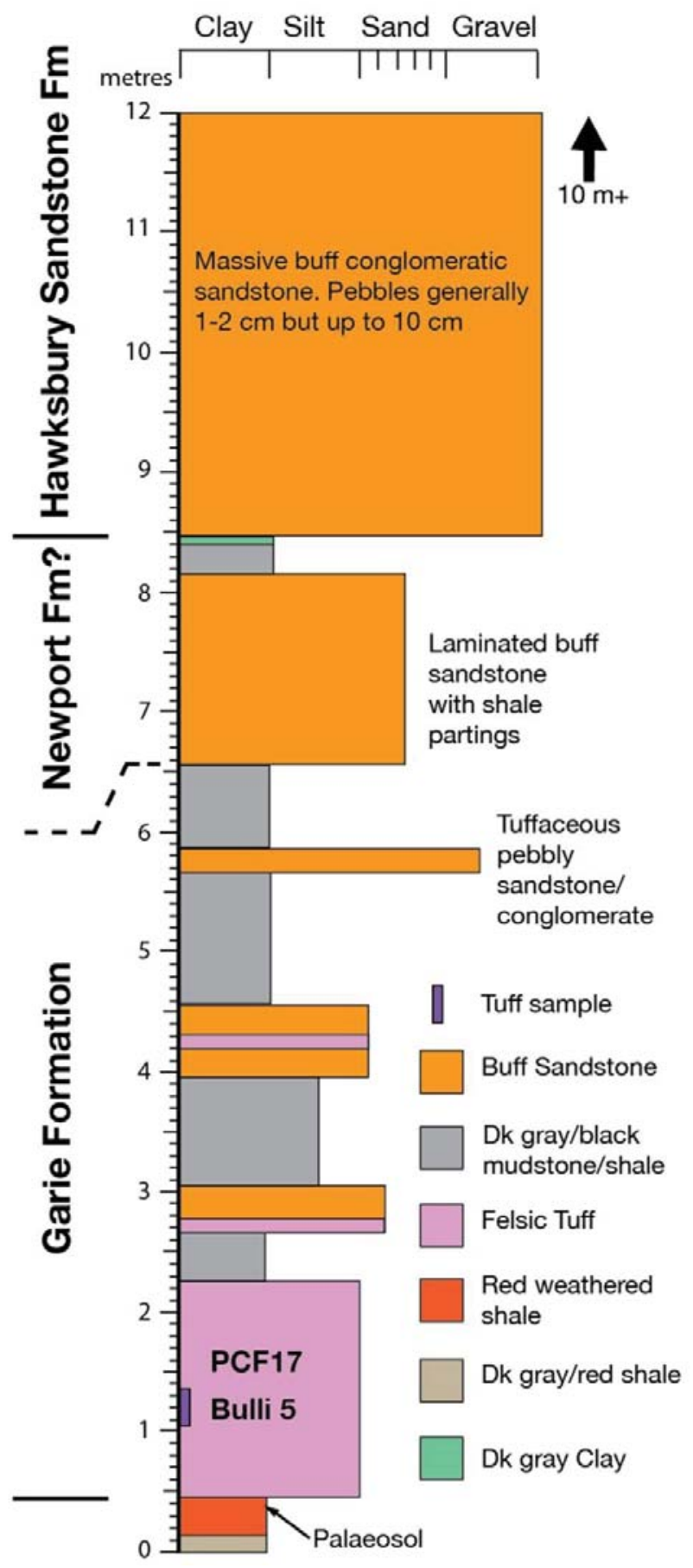

Figure 4 
This is an author-produced, peer-reviewed version of this article. The final, definitive version of this document can be found online at Gondwana Research, published by Elsevier Copyright restrictions may apply. doi: 10.1016/j.gr.2014.09.002

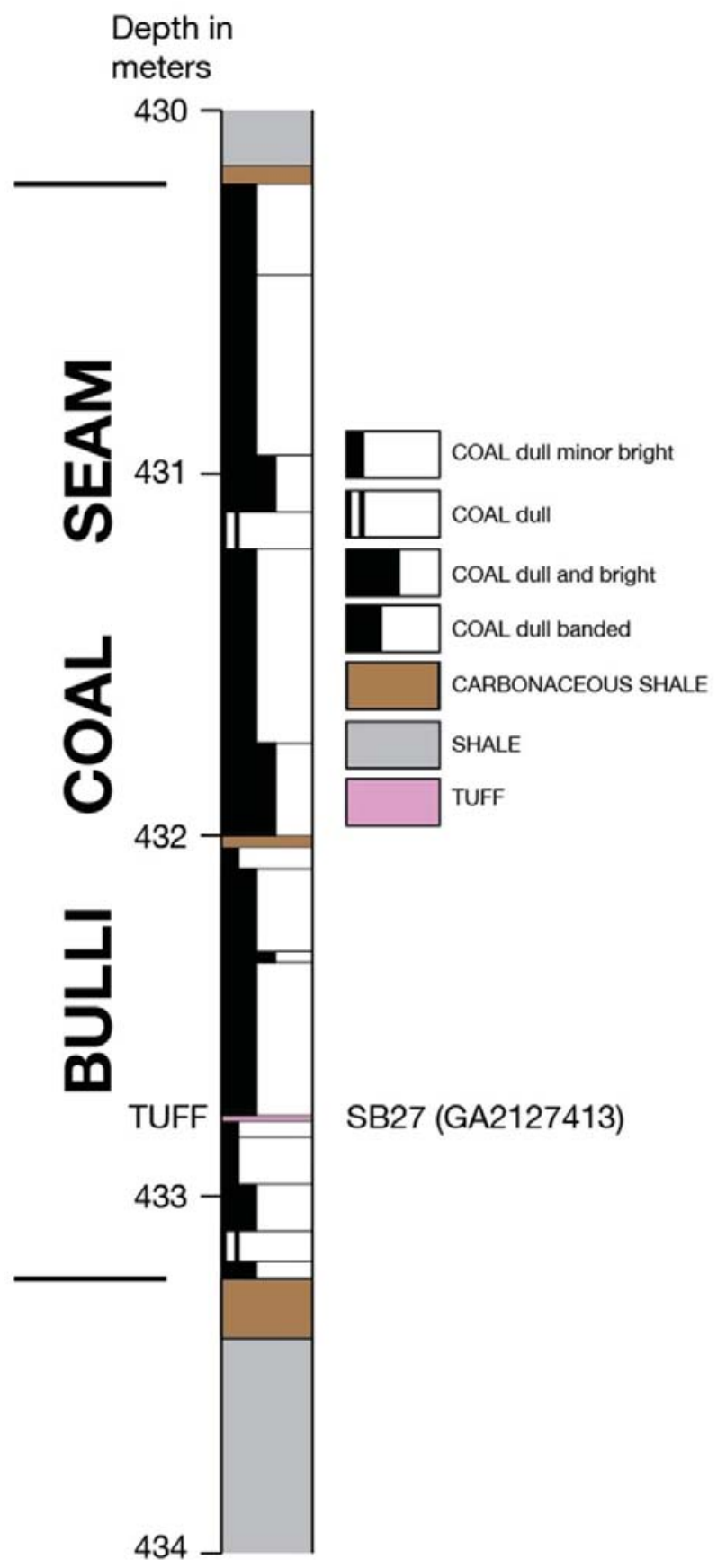

Figure 5 
This is an author-produced, peer-reviewed version of this article. The final, definitive version of this document can be found online at Gondwana Research, published by Elsevier Copyright restrictions may apply. doi: 10.1016/j.gr.2014.09.002

\section{Centennial PN072}

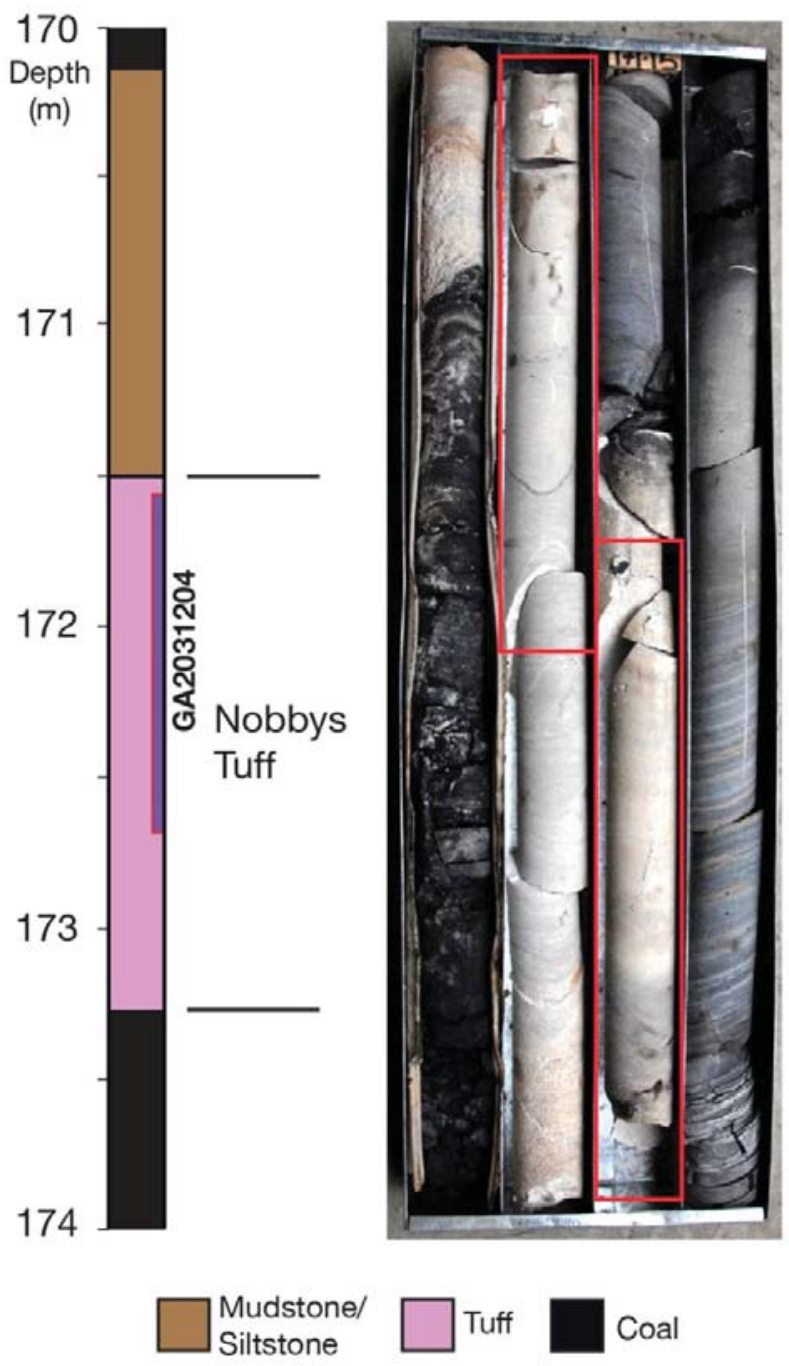

Figure 6 


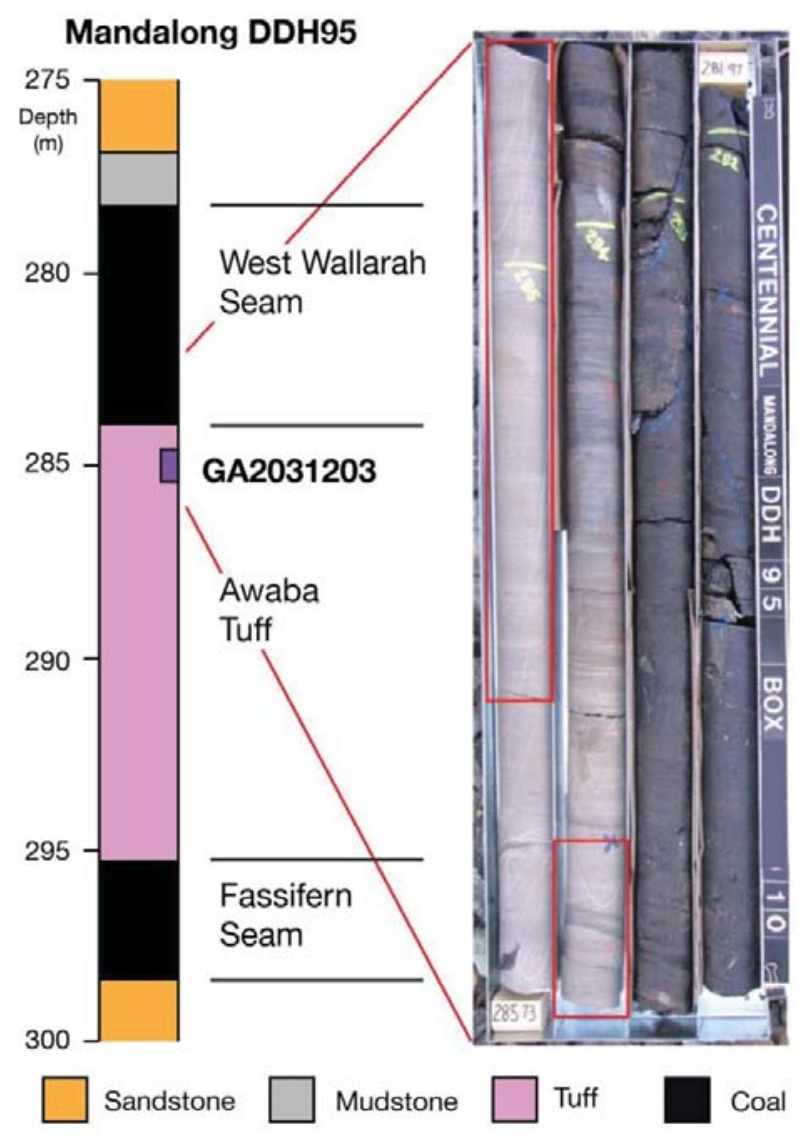

Figure 7 
TERALBA

CONGLOMERATE

AWABA TUFF

FASSIFERN SEAM

UPPER PILOT

SEAM

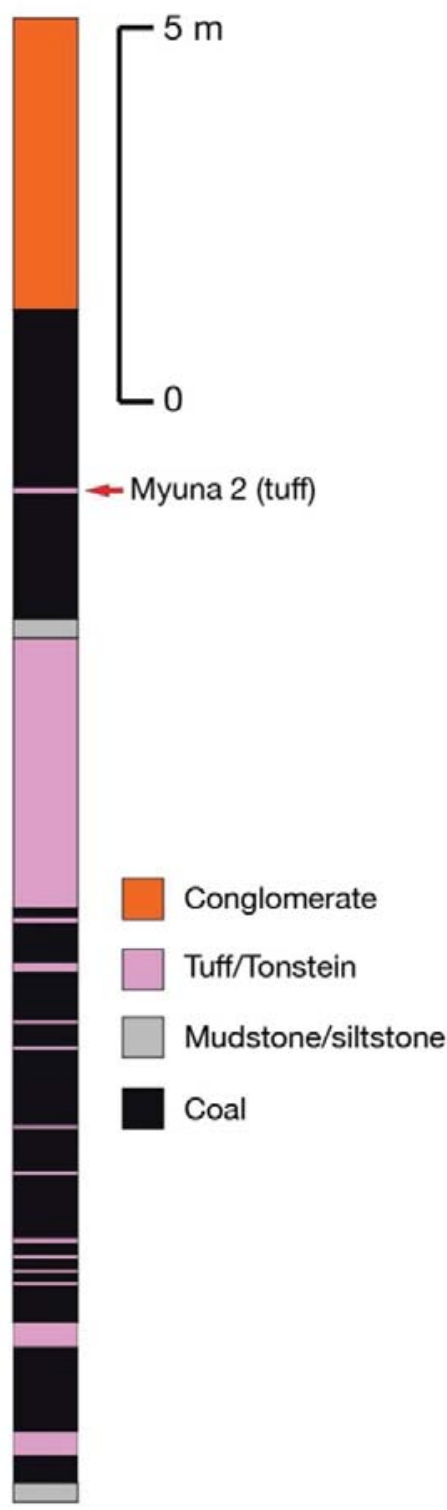

Figure 8 
Myuna DDH45

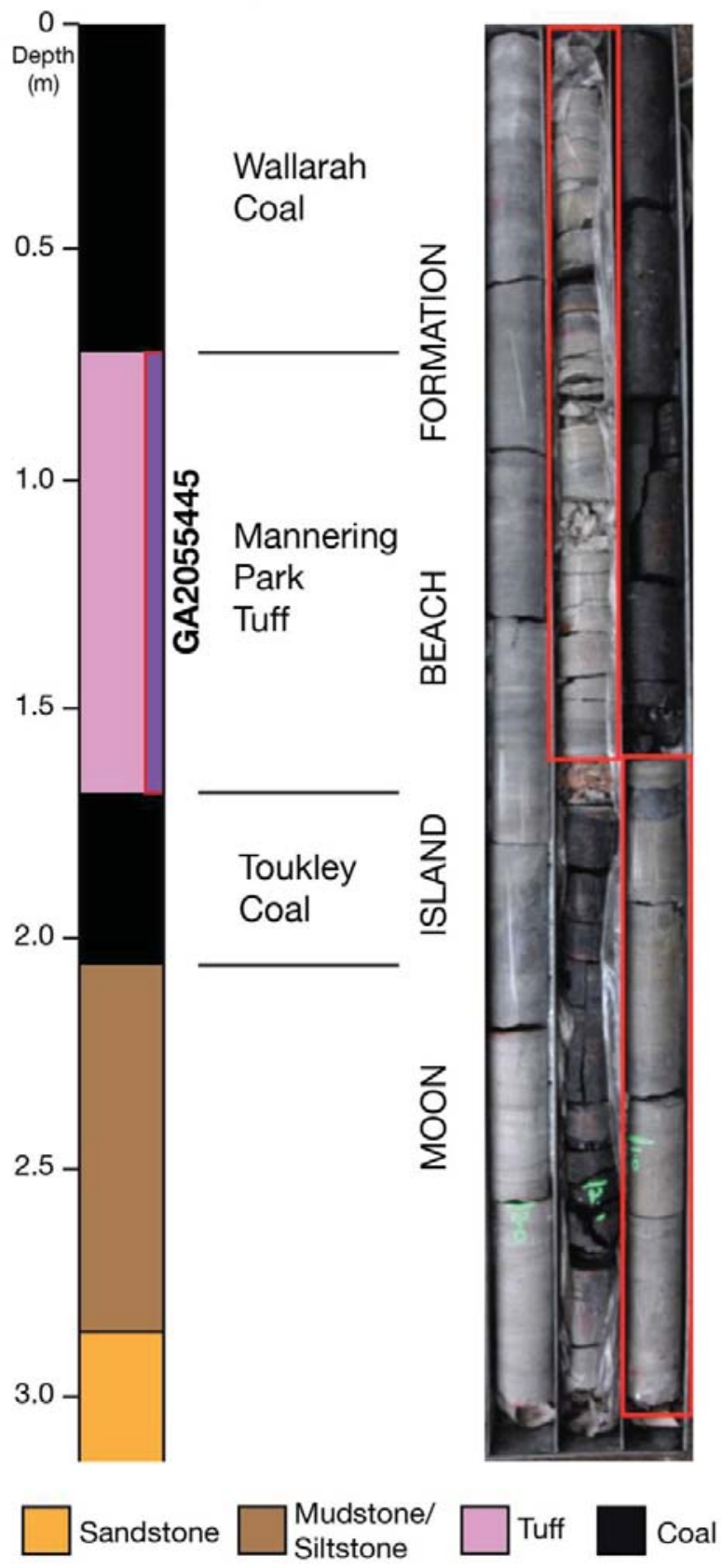

Figure 9 
This is an author-produced, peer-reviewed version of this article. The final, definitive version of this document can be found online at Gondwana Research, published by Elsevier Copyright restrictions may apply. doi: 10.1016/j.gr.2014.09.002

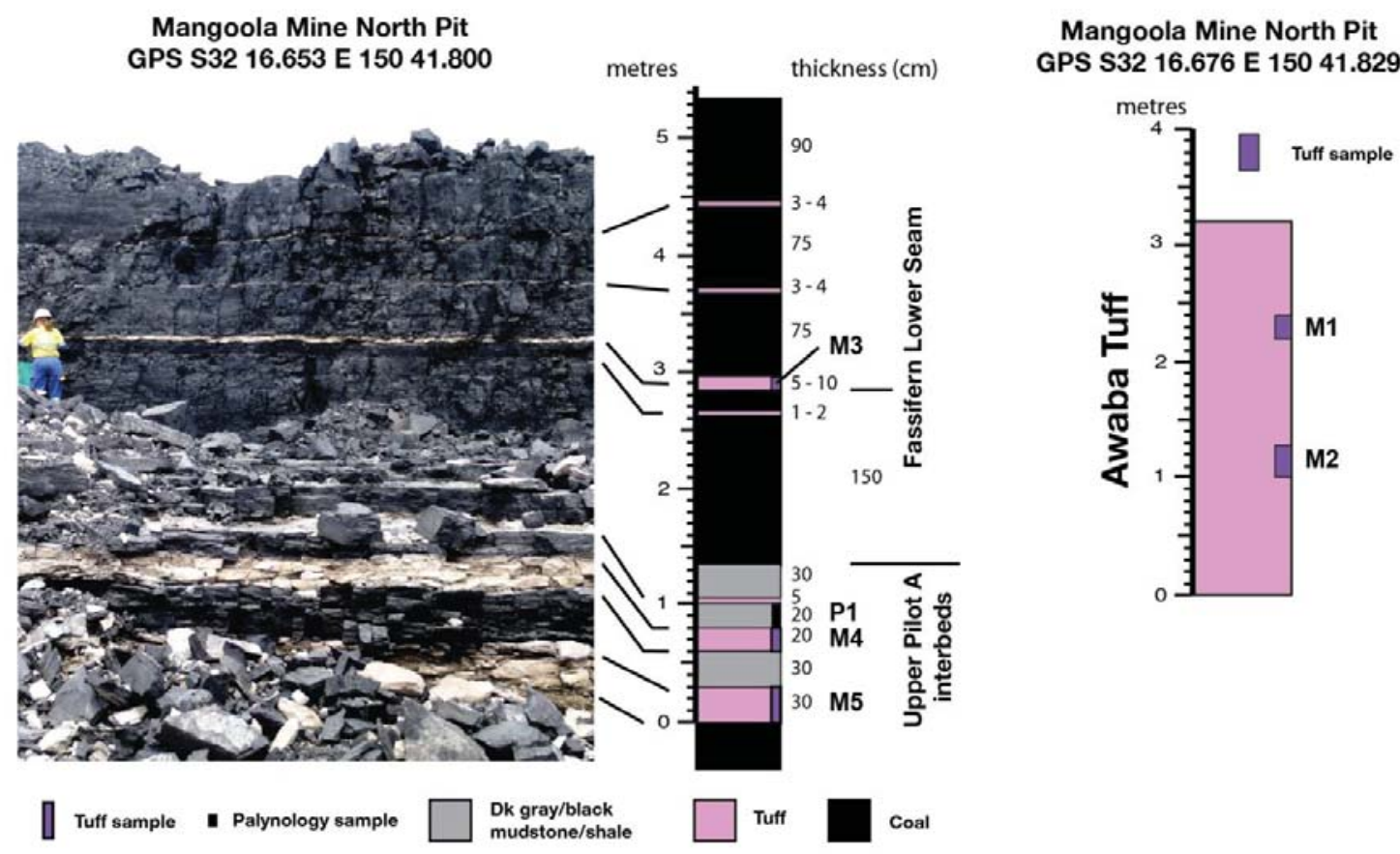

Figure 10 


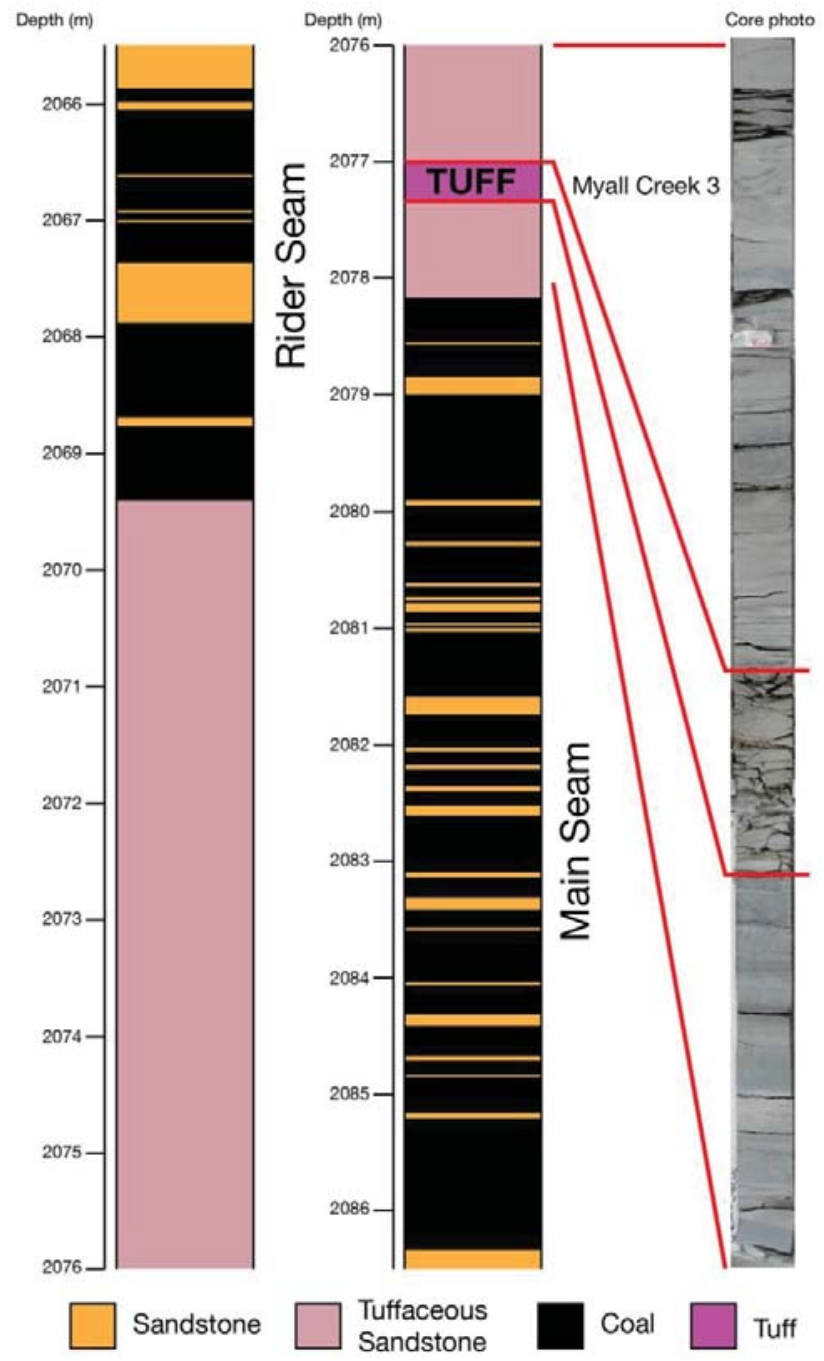

Figure 11 


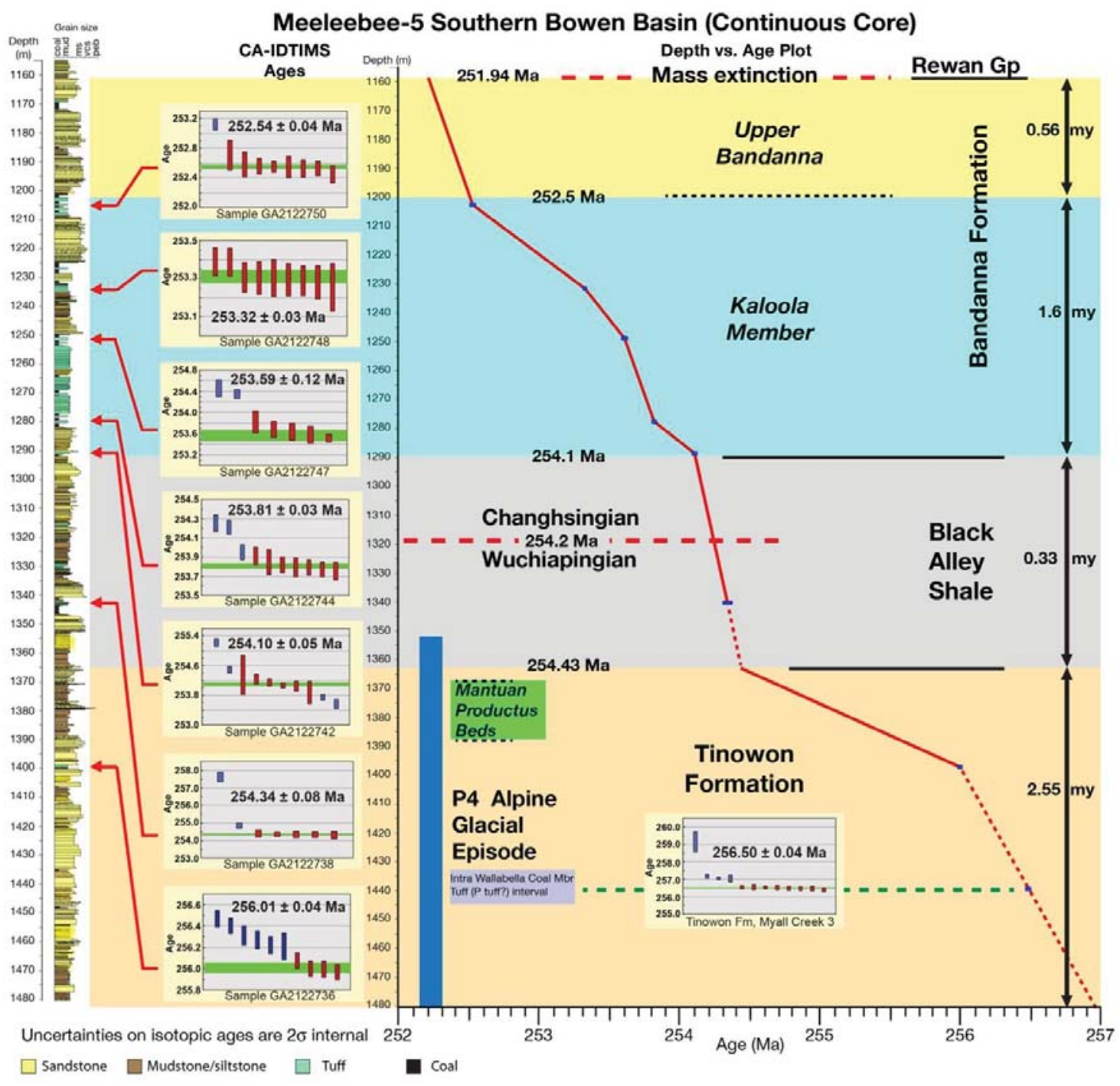

Figure 12 


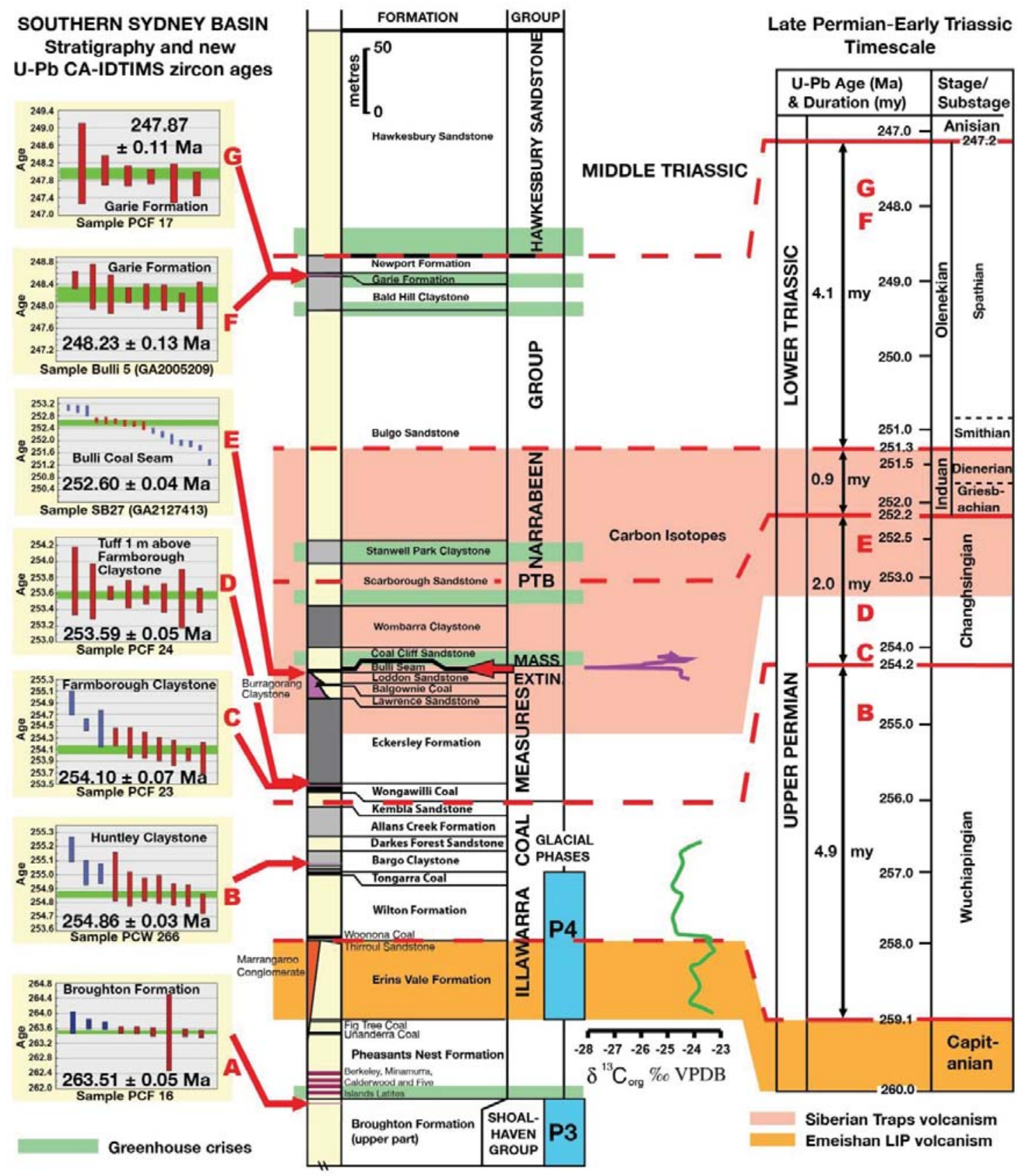

Conglomerate

Figure 13 
This is an author-produced, peer-reviewed version of this article. The final, definitive version of this document can be found online at Gondwana Research, published by Elsevier Copyright restrictions may apply. doi: 10.1016/j.gr.2014.09.002

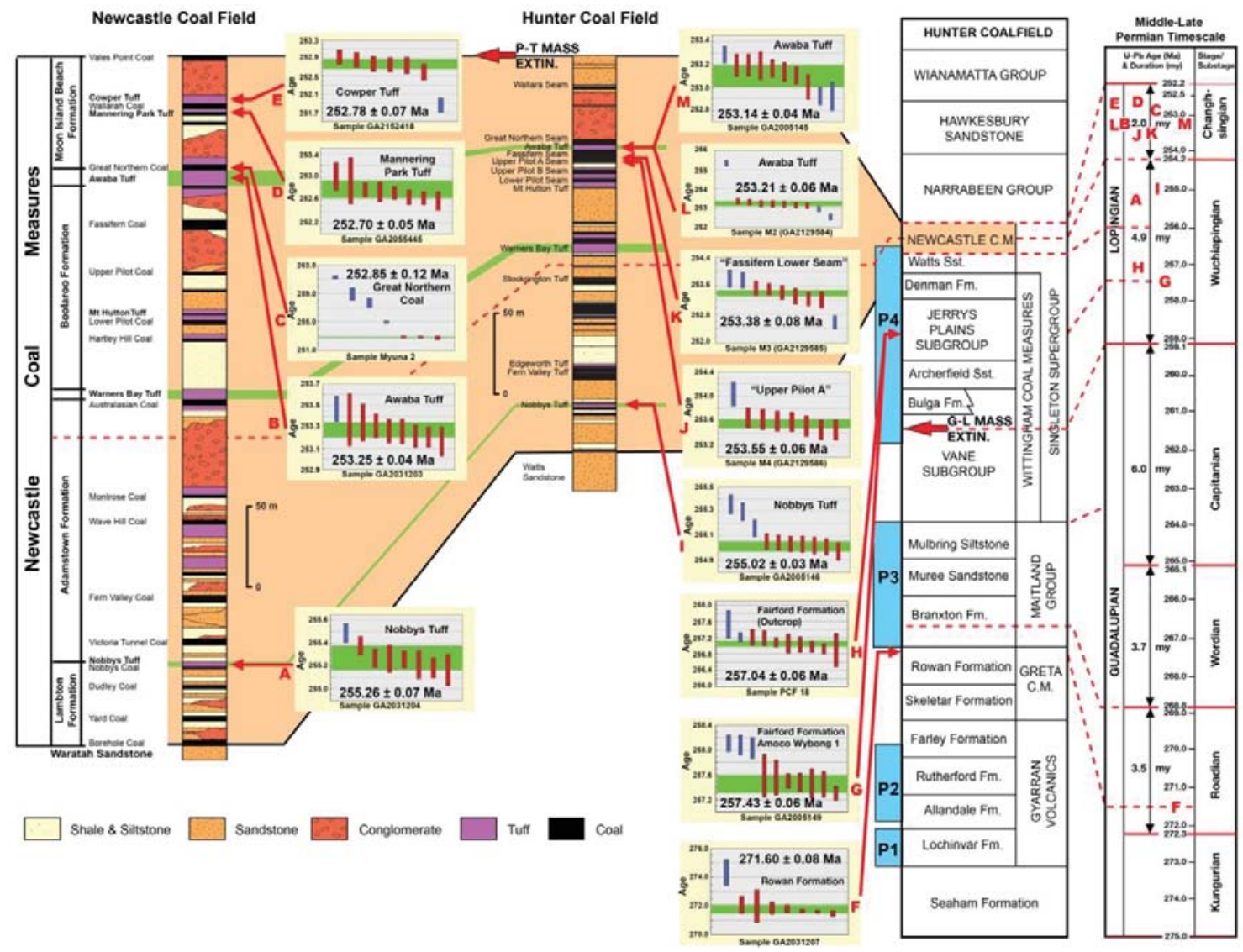

Figure 14 
This is an author-produced, peer-reviewed version of this article. The final, definitive version of this document can be found online at Gondwana Research, published by Elsevier Copyright restrictions may apply. doi: 10.1016/j.gr.2014.09.002

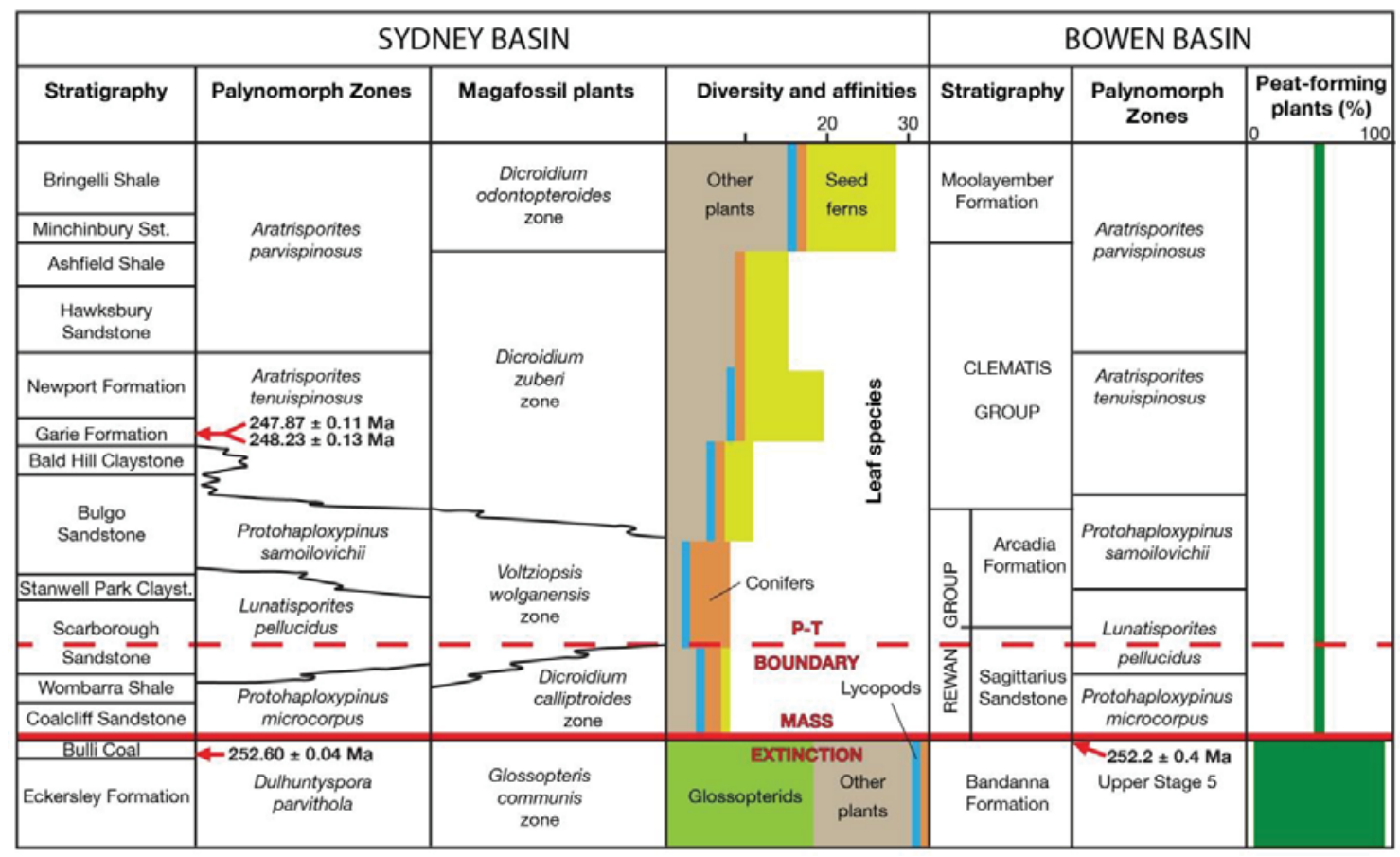

Figure 15 


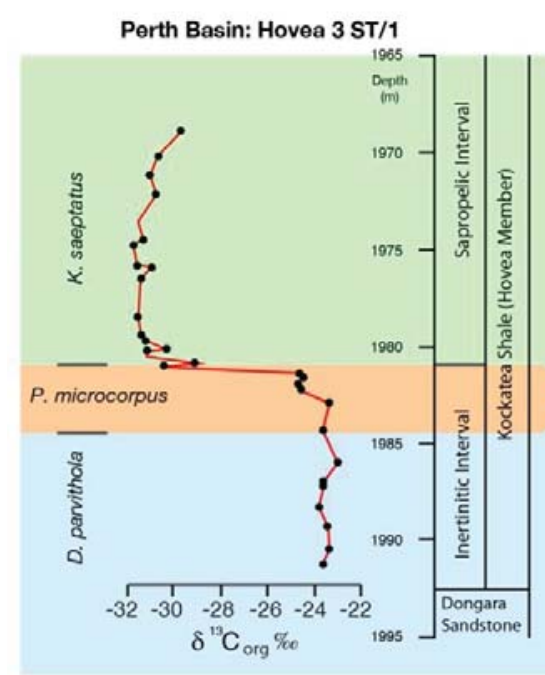

Canning Basin: Paradise Coreholes

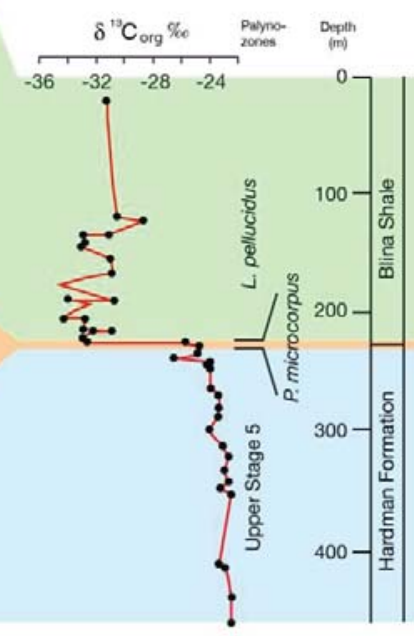

Sydney Basin:

Southern Sydney Basin: Douglas DDH15

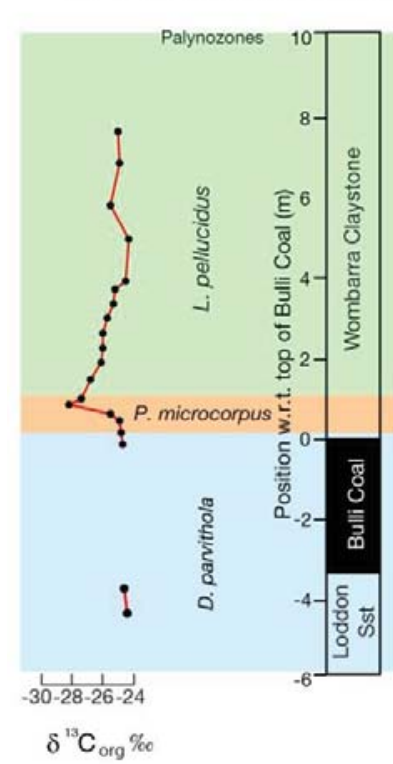

Bonaparte Basin: Tern-3

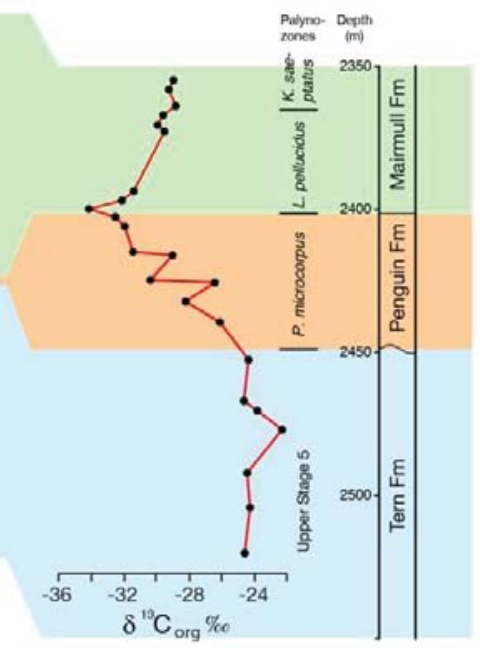

Bowen Basin: Denison NS 20 $\begin{array}{rrr}32-30-28-26-24-22 & 350- \\ -32 & \text { Depth }\end{array}$

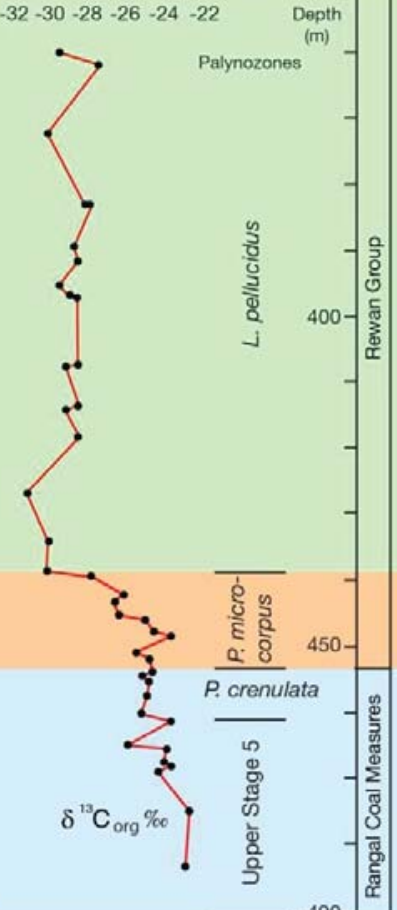

Figure 16 
This is an author-produced, peer-reviewed version of this article. The final, definitive version of this document can be found online at Gondwana Research, published by Elsevier Copyright restrictions may apply. doi: 10.1016/j.gr.2014.09.002

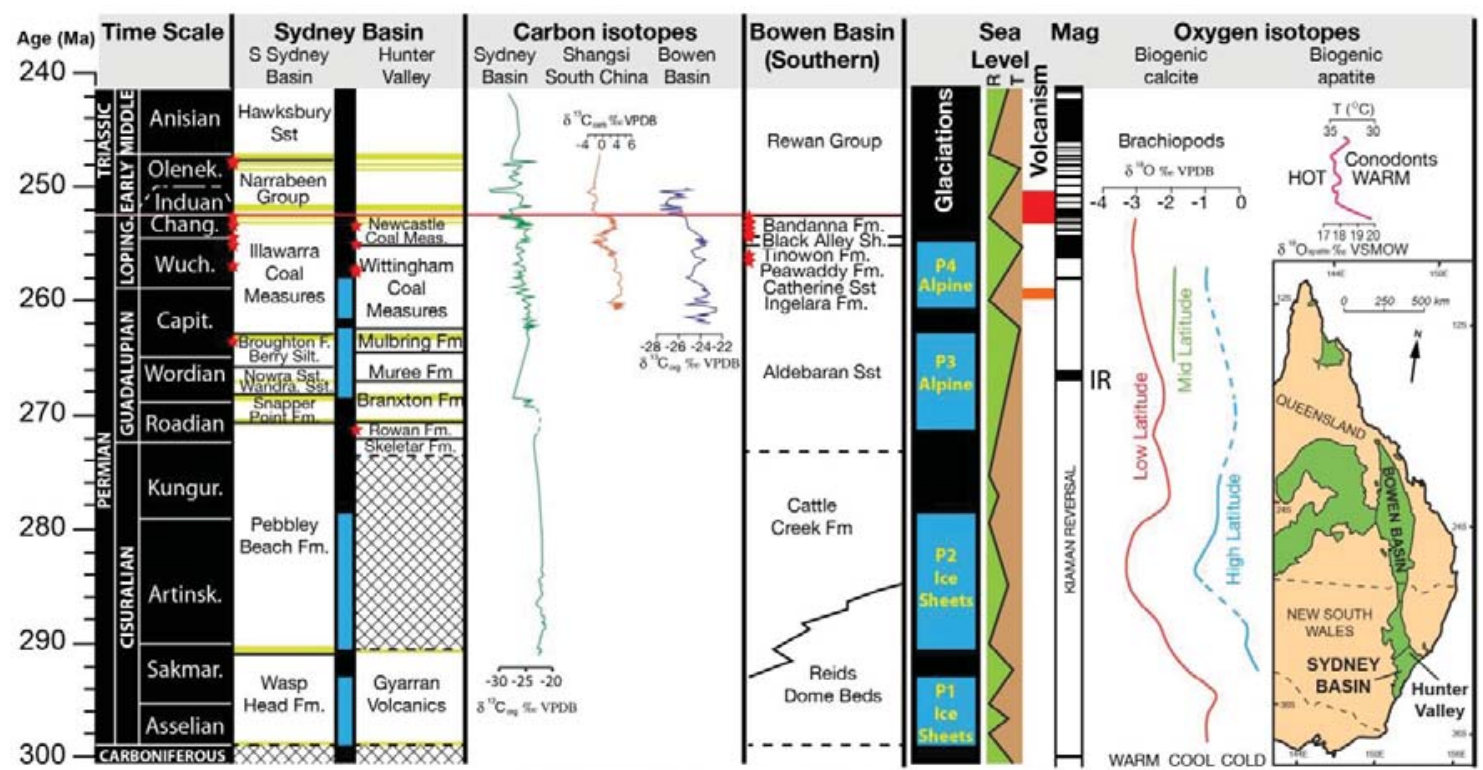

$\star$ New U-Pb single zircon CA-IDTIMS tuff ages $\square$ Stratigraphic break $\simeq$ Greenhouse crises Emeishan LIP volcanism

Figure 17 
Table 1. Tuff sample locality details.

\begin{tabular}{|c|c|c|c|c|c|c|}
\hline $\begin{array}{l}\text { Sample } \\
\text { Number }\end{array}$ & $\begin{array}{l}\text { Geoscience } \\
\text { Australia } \\
\text { Number }\end{array}$ & $\begin{array}{l}\text { GPS } \\
\text { (Lat/Long) }\end{array}$ & $\begin{array}{l}\text { Locality/ } \\
\text { Borehole }\end{array}$ & $\begin{array}{l}\text { Depth in } \\
\text { Borehole (m) }\end{array}$ & $\begin{array}{l}\text { Stratigraphic } \\
\text { Unit }\end{array}$ & Comments \\
\hline PCF16 & GA2168090 & $\begin{array}{l}\text { S34.408237 } \\
\text { E150.87857 }\end{array}$ & $\begin{array}{l}\text { Outcrop, } \\
\text { Wollongong } \\
\text { area. }\end{array}$ & $\mathrm{N} / \mathrm{A}$ & $\begin{array}{l}\text { Broughton } \\
\text { Formation, } \\
\text { Shoalhaven } \\
\text { Group }\end{array}$ & $\begin{array}{l}\text { Sample } 2 \mathrm{~m} \text { from top of Broughton Fm. } \\
\text { This sample re-dated from original } \\
\text { SHRIMP mount (Retallack et al., 2011). }\end{array}$ \\
\hline PCW266 & GA2168093 & $\begin{array}{l}\text { S34.185243 } \\
\text { E150.884432 }\end{array}$ & $\begin{array}{l}\text { Tower DDH } \\
20,6 \mathrm{~km} \\
\text { southeast of } \\
\text { Appin }\end{array}$ & 600.37 & $\begin{array}{l}\text { Huntley } \\
\text { Claystone } \\
\text { Member. } \\
\text { Illawarra Coal } \\
\text { Measures } \\
\end{array}$ & $\begin{array}{l}\text { This sample re-dated from original } \\
\text { SHRIMP mount (Retallack et al., 2011). } \\
\text { Sample was reported as from "Nattai } \\
\text { River" but location from Tower DDH20 } \\
\text { provided by Brian Jones (Pers. Comm.) }\end{array}$ \\
\hline PCF23 & GA2168091 & $\begin{array}{l}\text { S34.43569 } \\
\text { E150.45639 }\end{array}$ & $\begin{array}{l}\text { Outcrop, Nattai } \\
\text { River, } \\
\text { Wollongong } \\
\text { area }\end{array}$ & N/A & $\begin{array}{l}\text { Farmborough } \\
\text { Claystone, } \\
\text { Illawarra Coal } \\
\text { Measures }\end{array}$ & $\begin{array}{l}\text { This sample re-dated from original } \\
\text { SHRIMP mount (Retallack et al., 2011) }\end{array}$ \\
\hline PCF24 & GA2168092 & $\begin{array}{l}\text { S34.43569 } \\
\text { E150.45639 }\end{array}$ & $\begin{array}{l}\text { Outcrop, Nattai } \\
\text { River, } \\
\text { Wollongong } \\
\text { area }\end{array}$ & $\mathrm{N} / \mathrm{A}$ & $\begin{array}{l}\text { Wongawilli } \\
\text { Coal, Illawarra } \\
\text { Coal Measures }\end{array}$ & $\begin{array}{l}\text { Tuff } 1 \mathrm{~m} \text { above Farmborough Claystone. } \\
\text { This sample re-dated from original } \\
\text { SHRIMP mount (Retallack et al., 2011) }\end{array}$ \\
\hline SB27 & GA2127413 & $\begin{array}{l}\text { S34.187047 } \\
\text { E150.992334 }\end{array}$ & $\begin{array}{l}\text { Metropolitan } \\
\text { Colliery }\end{array}$ & N/A & $\begin{array}{l}\text { Bulli Coal } \\
\text { Seam, Illawarra } \\
\text { Coal Measures } \\
\end{array}$ & $\begin{array}{l}\text { Thin (1-2 cm thick) tuff in lower part of } \\
\text { Bulli Seam, } 0.61 \mathrm{~m} \text { above base of Bulli } \\
\text { Coal (see Fig. 5) }\end{array}$ \\
\hline Bulli 5 & GA2005209 & $\begin{array}{l}\text { S34.32926 } \\
\text { E150.8762321 }\end{array}$ & $\begin{array}{l}\text { Outcrop, } \\
\text { freeway cut, } \\
\text { Bulli Tops } \\
\end{array}$ & $\mathrm{N} / \mathrm{A}$ & $\begin{array}{l}\text { Garie } \\
\text { Formation }\end{array}$ & $\begin{array}{l}\text { Middle part of a } 1.8 \mathrm{~m} \text { thick felsic tuff } \\
\text { near the base of the Garie Formation. For } \\
\text { sample location details see Fig } 4 .\end{array}$ \\
\hline PCF17 & GA2168089 & $\begin{array}{l}\text { S34.32926 } \\
\text { E150.8762321 }\end{array}$ & $\begin{array}{l}\text { Outcrop, } \\
\text { freeway cut, } \\
\text { Bulli Tops }\end{array}$ & $\mathrm{N} / \mathrm{A}$ & $\begin{array}{l}\text { Garie } \\
\text { Formation }\end{array}$ & $\begin{array}{l}\text { This sample re-dated from original } \\
\text { SHRIMP mount (Retallack et al., 2011) }\end{array}$ \\
\hline GA2031204 & GA2031204 & $\begin{array}{l}\text { S33.016116, } \\
\text { E151.52842 }\end{array}$ & $\begin{array}{l}\text { Centennial } \\
\text { Borehole } \\
\text { PN072 }\end{array}$ & $171.57-172.67$ & $\begin{array}{l}\text { Nobbys Tuff, } \\
\text { Newcastle Coal } \\
\text { Measures }\end{array}$ & $\begin{array}{l}\text { Regional marker tuff in the lower part of } \\
\text { the Newcastle Coal Measures. For sample } \\
\text { location details see Fig } 6 \text {. }\end{array}$ \\
\hline GA2031203 & GA2031203 & $\begin{array}{l}\text { S33.1216825, } \\
\text { E151.425355 }\end{array}$ & $\begin{array}{l}\text { Centennial } \\
\text { Coal/ } \\
\text { Mandalong } \\
\text { DDH 95 }\end{array}$ & $284.63-285.44$ & $\begin{array}{l}\text { Awaba Tuff, } \\
\text { Newcastle Coal } \\
\text { Measures }\end{array}$ & $\begin{array}{l}\text { Uppermost part of the } 11.39 \mathrm{~m} \text { thick } \\
\text { Awaba tuff was sampled (see Fig. 7) }\end{array}$ \\
\hline Myuna 2 & GA2128524 & $\begin{array}{l}\text { S33.0631786, } \\
\text { E151.569965 }\end{array}$ & $\begin{array}{l}\text { Myuna Mine, } \\
\text { Newcastle }\end{array}$ & $\mathrm{N} / \mathrm{A}$ & $\begin{array}{l}\text { Great Northern } \\
\text { Coal Seam, } \\
\text { Newcastle } \\
\text { Coalfield, } \\
\text { Sydney Basin }\end{array}$ & $\begin{array}{l}\text { A tuff in the Middle part of the Great } \\
\text { Northern Seam was sampled and dated. } \\
\text { For sample location details see Fig } 8 \text {. }\end{array}$ \\
\hline GA2055445 & GA2055445 & $\begin{array}{l}\text { S33.0718, } \\
\text { E151.5988 }\end{array}$ & $\begin{array}{l}\text { Centennial } \\
\text { Coal, Myuna } \\
\text { DDH } 45\end{array}$ & $0.70-1.70 \mathrm{~m}$ & $\begin{array}{l}\text { Mannering Park } \\
\text { Tuff, Moon } \\
\text { Island Beach } \\
\text { Fm, Newcastle } \\
\text { Coal Measures } \\
\end{array}$ & $\begin{array}{l}\text { This } 1 \mathrm{~m} \text { thick tuff occurs directly beneath } \\
\text { the Wallarah Coal (Fig. 9). }\end{array}$ \\
\hline GA2152418 & GA2152418 & $\begin{array}{l}\text { S33.1774139, } \\
\text { E151.6297194 }\end{array}$ & Ghosties Beach & $\mathrm{N} / \mathrm{A}$ & $\begin{array}{l}\text { Cowper Tuff, } \\
\text { Newcastle Coal } \\
\text { Measures } \\
\end{array}$ & $\begin{array}{l}\text { Sample was collected below the Karignan } \\
\text { Conglomerate and above Wallarah Coal } \\
\text { seam in outcrop at Ghosties Beach (Fig. 3) }\end{array}$ \\
\hline GA2031207 & GA2031207 & $\begin{array}{l}\text { S33.0161208, } \\
\text { E151.528421 }\end{array}$ & $\begin{array}{l}\text { Muswellbrook } \\
\text { Coal Sandy } \\
\text { Creek DDH } 32 \\
\end{array}$ & $266.91-267.07$ & $\begin{array}{l}\text { Rowan Fm, } \\
\text { Newcastle Coal } \\
\text { Measures } \\
\end{array}$ & $\begin{array}{l}\text { Upper part of Rowan Formation, } \\
\text { approximately } 11 \mathrm{~m} \text { below the top of the } \\
\text { Rowan Formation }\end{array}$ \\
\hline GA2005149 & GA2005149 & $\begin{array}{l}\text { S32.27502, } \\
\text { E150.65368 }\end{array}$ & $\begin{array}{l}\text { AMACO } \\
\text { Wybong } 1\end{array}$ & $595.9-596.21$ & $\begin{array}{l}\text { Fairford Fm, } \\
\text { Wittingham } \\
\text { Coal Measures }\end{array}$ & Lower part of Jerrys Plains Subgroup \\
\hline PCF 18 & GA2168094 & $\begin{array}{l}\text { S32.329063 } \\
\text { E150.86629 }\end{array}$ & $\begin{array}{l}\text { Outcrop, } \\
\text { Mount Arthur } \\
\text { Mine, SSW of } \\
\text { Muswellbrook }\end{array}$ & $\mathrm{N} / \mathrm{A}$ & $\begin{array}{l}\text { Fairford Fm, } \\
\text { Wittingham } \\
\text { Coal Measures }\end{array}$ & $\begin{array}{l}\text { This sample re-dated from original } \\
\text { SHRIMP mount (Retallack et al., 2011) }\end{array}$ \\
\hline GA2005146 & GA2005146 & $\begin{array}{l}\text { S32.27502, } \\
\text { E150.65368 }\end{array}$ & $\begin{array}{l}\text { AMACO } \\
\text { Wybong } 1\end{array}$ & $255.33-255.6$ & $\begin{array}{l}\text { Nobbys Tuff } \\
\text { (Clifford } \\
\text { Formation), } \\
\text { Newcastle Coal } \\
\text { Measures }\end{array}$ & $\begin{array}{l}\text { Regional marker tuff in the lower part of } \\
\text { the Newcastle Coal Measures. See Creech } \\
\text { et al. (2004) for relevant stratigraphic } \\
\text { section. }\end{array}$ \\
\hline M4 & GA2129586 & $\begin{array}{l}\text { S32.277529, } \\
\text { E150.696677 }\end{array}$ & $\begin{array}{l}\text { Mangoola } \\
\text { Mine (North } \\
\text { Pit), Wybong }\end{array}$ & $\mathrm{N} / \mathrm{A}$ & $\begin{array}{l}\text { Upper Pilot } \\
\text { Coal A } \\
\text { interbeds }\end{array}$ & For sample location details see Fig 10. \\
\hline$\overline{\mathrm{M} 3}$ & GA2129585 & $\begin{array}{l}\text { S32.277529, } \\
\text { E150.696677 }\end{array}$ & $\begin{array}{l}\text { Mangoola } \\
\text { Mine (North } \\
\text { Pit), Wybong }\end{array}$ & $\mathrm{N} / \mathrm{A}$ & $\begin{array}{l}\text { Fassifern Lower } \\
\text { Seam }\end{array}$ & For sample location details see Fig 10. \\
\hline M2 & GA2129584 & $\begin{array}{l}\text { S32.277903, } \\
\text { E150.697191 }\end{array}$ & $\begin{array}{l}\text { Mangoola } \\
\text { Mine }\end{array}$ & N/A & $\begin{array}{l}\text { Awaba Tuff } \\
\text { (lower part) }\end{array}$ & $\begin{array}{l}\text { For sample location details see Fig } 10 . \\
\text { Regional marker tuff in the upper part of } \\
\text { the Newcastle Coal Measures }\end{array}$ \\
\hline
\end{tabular}


This is an author-produced, peer-reviewed version of this article. The final, definitive version of this document can be found online at Gondwana Research, published by Elsevier Copyright restrictions may apply. doi: 10.1016/j.gr.2014.09.002

\begin{tabular}{|c|c|c|c|c|c|c|}
\hline GA2005145 & GA2005145 & $\begin{array}{l}\text { S32.27502, } \\
\text { E150.65368 }\end{array}$ & $\begin{array}{l}\text { AMACO } \\
\text { Wybong } 1\end{array}$ & $94.92-95.2$ & $\begin{array}{l}\text { Awaba } \\
\text { (Nalleen) Tuff } \\
\text { (lower part) }\end{array}$ & $\begin{array}{l}\text { Regional marker tuff in the upper part of } \\
\text { the Newcastle Coal Measures. See Creech } \\
\text { et al. (2004) for relevant stratigraphic } \\
\text { section. }\end{array}$ \\
\hline $\begin{array}{l}\text { Myall } \\
\text { Creek } 3\end{array}$ & GA2171609 & $\begin{array}{l}\text { S27.069627, } \\
\text { E149.216035 }\end{array}$ & Myall Creek 3 & $\begin{array}{l}2077.01- \\
2077.35\end{array}$ & $\begin{array}{l}\text { Tinowon Fm, } \\
\text { Wallabella Coal } \\
\text { Member }\end{array}$ & $\begin{array}{l}34 \mathrm{~cm} \text { thick air fall tuff near the base of an } \\
8.6 \mathrm{~m} \text { thick re-worked tuffaceous } \\
\text { sst/mudstone unit within the Wallabella } \\
\text { Coal. See Fig. } 11 .\end{array}$ \\
\hline GA2122736 & GA2122736 & $\begin{array}{l}\text { S26.241774, } \\
\text { E149.197463 }\end{array}$ & $\begin{array}{l}\text { Origin Energy } \\
\text { Meeleebee } 5\end{array}$ & $\begin{array}{l}1398.70- \\
1399.42 \\
\end{array}$ & Tinov & Upper part of Tinowon (see Fig. 12) \\
\hline GA2122738 & GA2122738 & $\begin{array}{l}\text { S26.241774, } \\
\text { E149.197463 }\end{array}$ & $\begin{array}{l}\text { Origin Energy } \\
\text { Meeleebee } 5\end{array}$ & $\begin{array}{l}1342.82 \text { - } \\
1343.00\end{array}$ & $\begin{array}{l}\text { Black Alley } \\
\text { Shale }\end{array}$ & Lower part of Black Alley (see Fig. 12) \\
\hline GA2122742 & GA2122742 & $\begin{array}{l}\text { S26.241774, } \\
\text { E149.197463 }\end{array}$ & $\begin{array}{l}\text { Origin Energy } \\
\text { Meeleebee } 5\end{array}$ & $\begin{array}{l}1290.16 \text { - } \\
1291.11\end{array}$ & $\begin{array}{l}\text { Kaloola Mbr, } \\
\text { Bandanna Fm }\end{array}$ & Basal part of Kaloola Mbr (see Fig. 12) \\
\hline GA2122744 & GA2122744 & $\begin{array}{l}\text { S26.241774, } \\
\text { E149.197463 }\end{array}$ & $\begin{array}{l}\text { Origin Energy } \\
\text { Meeleebee } 5\end{array}$ & $\begin{array}{l}1279.50 \text { - } \\
1280.25\end{array}$ & $\begin{array}{l}\text { Kaloola Mbr, } \\
\text { Bandanna Fm }\end{array}$ & Lower part of Kaloola Mbr (see Fig. 12) \\
\hline GA2122747 & GA2122747 & $\begin{array}{l}\text { S26.241774, } \\
\text { E149.197463 }\end{array}$ & $\begin{array}{l}\text { Origin Energy } \\
\text { Meeleebee } 5\end{array}$ & $\begin{array}{l}1250.61 \text { - } \\
1251.82\end{array}$ & $\begin{array}{l}\text { Kaloola Mbr, } \\
\text { Bandanna Fm }\end{array}$ & Middle part of Kaloola Mbr (see Fig. 12) \\
\hline GA2122748 & GA2122748 & $\begin{array}{l}\text { S26.241774, } \\
\text { E149.197463 }\end{array}$ & $\begin{array}{l}\text { Origin Energy } \\
\text { Meeleebee } 5\end{array}$ & $\begin{array}{l}1233.34- \\
1234.56 \\
\end{array}$ & $\begin{array}{l}\text { Kaloola Mbr, } \\
\text { Bandanna Fm }\end{array}$ & Middle part of Kaloola Mbr (see Fig. 12) \\
\hline GA2122750 & GA2122750 & $\begin{array}{l}\text { S26.241774, } \\
\text { E149.197463 }\end{array}$ & $\begin{array}{l}\text { Origin Energy } \\
\text { Meeleebee } 5\end{array}$ & $\begin{array}{l}1203.31- \\
1203.42\end{array}$ & $\begin{array}{l}\text { Kaloola Mbr, } \\
\text { Bandanna Fm }\end{array}$ & Top of Kaloola Mbr (see Fig. 12) \\
\hline
\end{tabular}


Table 2. Weighted mean dates interpreted as depositional ages of tuff samples and uncertainties ( $\mathrm{x}$ is the internal error, $\mathrm{y}$ is the error including tracer calibration uncertainty, and $\mathrm{z}$ is the error including decay constant uncertainty). MSWD $=$ Mean square weighted deviation. POF = Probability of fit.

\begin{tabular}{|c|c|c|c|c|c|c|c|}
\hline Sample No. & $\begin{array}{l}\text { Age } \\
\text { (Ma) }\end{array}$ & $\bar{x}$ & $\mathbf{y}$ & $\mathbf{z}$ & MSWD & POF & Comments \\
\hline PCF16 & 263.51 & \pm 0.05 & \pm 0.14 & \pm 0.31 & 0.6 & 0.72 & $\begin{array}{l}\text { Six youngest dates yield a weighted mean date of } 263.51 \mathrm{Ma} \text {. } \\
\text { Three older dates from two grains are } 263.67 \pm 0.09 \text { to } 263.76 \pm \\
0.30 \mathrm{Ma} \text {. }\end{array}$ \\
\hline PCW266 & 254.86 & \pm 0.03 & \pm 0.13 & \pm 0.30 & 1.2 & 0.30 & $\begin{array}{l}\text { Seven youngest dates yield a weighted mean date of } 254.86 \mathrm{Ma} \text {. } \\
\text { Three older dates are } 255.01 \pm 0.07 \text { to } 255.18 \pm 0.09 \mathrm{Ma} \text {. }\end{array}$ \\
\hline PCF23 & 254.10 & \pm 0.12 & \pm 0.18 & \pm 0.32 & 2.2 & 0.04 & $\begin{array}{l}\text { Seven youngest dates yield a weighted mean date of } 254.10 \text {. } \\
\text { Three older dates are } 254.46 \pm 0.32 \text { to } 254.90 \pm 0.21 \text { Ma. }\end{array}$ \\
\hline PCF24 & 253.59 & \pm 0.05 & \pm 0.14 & \pm 0.30 & 0.3 & 0.95 & Eight dates yield a weighted mean date of $253.59 \mathrm{Ma}$. \\
\hline SB27 & 252.60 & \pm 0.04 & \pm 0.13 & \pm 0.30 & 1.6 & 0.15 & $\begin{array}{l}\text { Six dates yield a weighted mean date of } 252.60 \mathrm{Ma} \text {. Three older } \\
\text { dates are } 252.97 \pm 0.17 \text { to } 253.07 \pm 0.09 \mathrm{Ma} \text {. Seven younger } \\
\text { dates are } 252.32 \pm 0.09 \text { to } 251.29 \pm 0.10 \mathrm{Ma} \text {. }\end{array}$ \\
\hline Bulli 5 & 248.23 & \pm 0.13 & \pm 0.18 & \pm 0.32 & 2.2 & 0.03 & Eight dates yield a weighted mean date of $248.23 \mathrm{Ma}$. \\
\hline PCF17 & 247.87 & \pm 0.11 & \pm 0.16 & \pm 0.31 & 0.6 & 0.71 & $\begin{array}{l}\text { Six youngest dates yield a weighted mean date of } 247.87 \mathrm{Ma} \text {. } \\
\text { Two older dates are } 263.26 \pm 0.51 \text { and } 326.35 \pm 0.45 \mathrm{Ma} \text {. }\end{array}$ \\
\hline GA2031204 & 255.26 & \pm 0.07 & \pm 0.14 & \pm 0.31 & 2.2 & 0.04 & $\begin{array}{l}\text { Seven youngest dates yield a weighted mean date of } 255.26 \mathrm{Ma} \text {. } \\
\text { One older date is } 255.49 \pm 0.09 \mathrm{Ma} \text {. }\end{array}$ \\
\hline GA2031203 & 253.25 & \pm 0.04 & \pm 0.13 & \pm 0.30 & 0.9 & 0.54 & $\begin{array}{l}\text { Eight youngest dates yield a weighted mean date of } 253.25 \pm \\
0.04 \text { Ma. One older date is } 253.47 \pm 0.12 \mathrm{Ma} \text {. }\end{array}$ \\
\hline Myuna 2 & 252.85 & \pm 0.12 & \pm 0.17 & \pm 0.32 & 0.3 & 0.74 & $\begin{array}{l}\text { Three youngest dates yield a weighted mean date of } 252.85 \mathrm{Ma} \text {. } \\
\text { Four older dates are } 255.00 \pm 0.19 \text { to } 294.73 \pm 0.60 \mathrm{Ma} \text {. }\end{array}$ \\
\hline GA2055445 & 252.70 & \pm 0.05 & \pm 0.13 & \pm 0.30 & 1.9 & 0.06 & $\begin{array}{l}\text { Eight youngest dates yield a weighted mean date of } 252.70 \mathrm{Ma} \text {. } \\
\text { One older date is } 340.10 \pm 1.14 \mathrm{Ma} \text {. }\end{array}$ \\
\hline GA2152418 & 252.78 & \pm 0.07 & \pm 0.14 & \pm 0.30 & 1.8 & 0.12 & $\begin{array}{l}\text { Six oldest dates yield a weighted mean date of } 252.78 \mathrm{Ma} \text {. One } \\
\text { younger date is } 251.85 \pm 0.16 \mathrm{Ma} \text {. }\end{array}$ \\
\hline GA2031207 & 271.60 & \pm 0.08 & \pm 0.15 & \pm 0.33 & 1.3 & 0.25 & $\begin{array}{l}\text { Seven youngest dates yield a weighted mean date of } 271.60 \mathrm{Ma} \text {. } \\
\text { One older date is } 274.33 \pm 0.90 \mathrm{Ma} \text {. }\end{array}$ \\
\hline GA2005149 & 257.43 & \pm 0.06 & \pm 0.14 & \pm 0.31 & 1.4 & 0.20 & $\begin{array}{l}\text { Seven youngest dates yield a weighted mean date of } 257.43 \pm \\
0.06 \text { Ma. Three older dates are } 258.03 \pm 0.17 \text { to } 258.11 \pm 0.14 \\
\text { Ma. }\end{array}$ \\
\hline PCF18 & 257.04 & \pm 0.06 & \pm 0.14 & \pm 0.31 & 1.6 & 0.14 & $\begin{array}{l}\text { Eight youngest dates yield a weighted mean date of } 257.04 \mathrm{Ma} \text {. } \\
\text { Two older dates are } 257.22 \pm 0.11 \text { and } 257.53 \pm 0.34 \mathrm{Ma} \text {. }\end{array}$ \\
\hline GA2005146 & 255.02 & \pm 0.03 & \pm 0.13 & \pm 0.30 & 0.6 & 0.14 & $\begin{array}{l}\text { Seven youngest dates yield a weighted mean date of } 255.02 \mathrm{Ma} \text {. } \\
\text { Three older dates are } 255.16 \pm 0.07 \text { to } 255.36 \pm 0.08 \mathrm{Ma} \text {. }\end{array}$ \\
\hline M4 & 253.55 & \pm 0.06 & \pm 0.14 & \pm 0.30 & 1.0 & 0.46 & $\begin{array}{l}\text { Seven youngest dates yield a weighted mean date of } 253.55 \mathrm{Ma} \text {. } \\
\text { One older date is } 254.04 \pm 0.20 \mathrm{Ma} \text {. }\end{array}$ \\
\hline M3 & 253.38 & \pm 0.08 & \pm 0.15 & \pm 0.31 & 1.8 & 0.11 & $\begin{array}{l}\text { Six dates yield a weighted mean date of } 253.38 \pm 0.08 \mathrm{Ma} \text {. Two } \\
\text { older dates are } 253.76 \pm 0.22 \text { and } 253.80 \pm 0.24 \mathrm{Ma} \text {. One } \\
\text { younger date is } 252.57 \pm 0.19 \mathrm{Ma} \text {. }\end{array}$ \\
\hline M2 & 253.21 & \pm 0.06 & \pm 0.14 & \pm 0.30 & 1.0 & 0.39 & $\begin{array}{l}\text { Seven dates yield a weighted mean date of } 253.21 \mathrm{Ma} \text {. One older } \\
\text { date is } 255.34 \pm 0.16 \mathrm{Ma} \text {. Two younger dates are } 252.53 \text { and } \\
252.92 \pm 0.16 \mathrm{Ma} \text {. }\end{array}$ \\
\hline GA2005145 & 253.14 & \pm 0.04 & \pm 0.13 & \pm 0.30 & 1.7 & 0.11 & $\begin{array}{l}\text { Seven dates yield a weighted mean date of } 253.14 \pm 0.04 \mathrm{Ma} \text {. } \\
\text { One older date is } 253.29 \pm 0.08 \mathrm{Ma} \text {. Two younger dates are } \\
252.92 \pm 0.08 \text { and } 252.92 \pm 0.13 \mathrm{Ma} \text {. }\end{array}$ \\
\hline $\begin{array}{l}\text { Myall Creek } \\
3\end{array}$ & 256.50 & \pm 0.04 & \pm 0.13 & \pm 0.30 & 0.8 & 0.59 & $\begin{array}{l}\text { Eight youngest dates yield a weighted mean date of } 256.50 \mathrm{Ma} \text {. } \\
\text { Four older dates are } 256.55 \pm 0.10 \text { to } 259.16 \pm 0.58 \mathrm{Ma} \text {. }\end{array}$ \\
\hline GA2122736 & 256.01 & \pm 0.04 & \pm 0.13 & \pm 0.30 & 1.5 & 0.21 & $\begin{array}{l}\text { Four youngest dates yield a weighted mean date of } 256.01 \mathrm{Ma} \text {. } \\
\text { Six older dates are } 256.21 \pm 0.13 \text { to } 256.47 \pm 0.08 \mathrm{Ma} \text {. }\end{array}$ \\
\hline GA2122738 & 254.34 & \pm 0.08 & \pm 0.15 & \pm 0.31 & 0.1 & 0.98 & $\begin{array}{l}\text { Five youngest dates yield a weighted mean date of } 254.34 \mathrm{Ma} \text {. } \\
\text { Two older dates are } 254.84 \pm 0.16 \text { to } 300.31 \pm 0.55 \mathrm{Ma} \text {. }\end{array}$ \\
\hline GA2122742 & 254.10 & \pm 0.05 & \pm 0.13 & \pm 0.30 & 1.9 & 0.09 & $\begin{array}{l}\text { Six dates yield a weighted mean date of } 254.10 \mathrm{Ma} \text {. Two older } \\
\text { dates are } 254.49 \pm 0.09 \text { and } 255.22 \pm 0.10 \mathrm{Ma} \text {. Two younger } \\
\text { dates are } 253.56 \pm 0.12 \text { and } 253.75 \pm 0.08 \mathrm{Ma} \text {. }\end{array}$ \\
\hline GA2122744 & 253.81 & \pm 0.03 & \pm 0.13 & \pm 0.30 & 1.4 & 0.21 & $\begin{array}{l}\text { Seven youngest dates yield a weighted mean date of } 253.81 \mathrm{Ma} \text {. } \\
\text { Three older dates are } 253.95 \pm 0.08 \text { to } 254.25 \pm 0.09 \mathrm{Ma} \text {. }\end{array}$ \\
\hline GA2122747 & 253.59 & \pm 0.12 & \pm 0.17 & \pm 0.32 & 2.6 & 0.04 & $\begin{array}{l}\text { Five youngest dates yield a weighted mean date of } 253.59 \mathrm{Ma} \text {. } \\
\text { Three older dates are } 254.34 \pm 0.09 \text { to } 259.13 \pm 1.07 \mathrm{Ma} \text {. }\end{array}$ \\
\hline GA2122748 & 253.32 & \pm 0.03 & \pm 0.13 & \pm 0.30 & 1.2 & 0.27 & Nine dates yield a weighted mean date of $253.32 \mathrm{Ma}$. \\
\hline GA2122750 & 252.54 & \pm 0.04 & \pm 0.13 & \pm 0.31 & 0.8 & 0.58 & $\begin{array}{l}\text { Eight dates yield a weighted mean date of } 252.54 \mathrm{Ma} \text {. One older } \\
\text { date is } 253.13 \pm 0.08 \mathrm{Ma} \text {. }\end{array}$ \\
\hline
\end{tabular}


This is an author-produced, peer-reviewed version of this article. The final, definitive version of this document can be found online at Gondwana Research, published by Elsevier Copyright restrictions may apply. doi: 10.1016/j.gr.2014.09.002
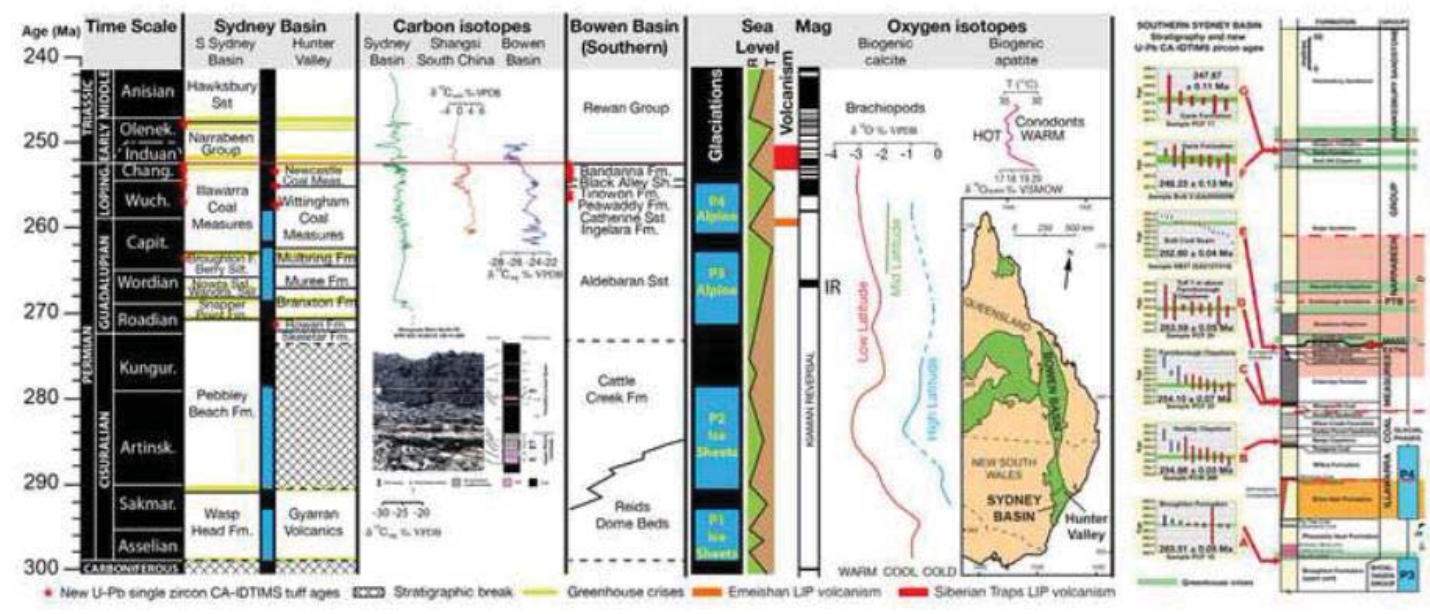

Graphical abstract 
This is an author-produced, peer-reviewed version of this article. The final, definitive version of this document can be found online at Gondwana Research, published by Elsevier Copyright restrictions may apply. doi: 10.1016/j.gr.2014.09.002

\section{Research Highlights}

28 high-precision U-Pb CA-TIMS tuff ages calibrate Permian-Triassic of E. Australia Ages of major climate change (glaciations, greenhouse crises) in E. Australia revised

End-Permian mass extinction interpreted to be synchronous globally 